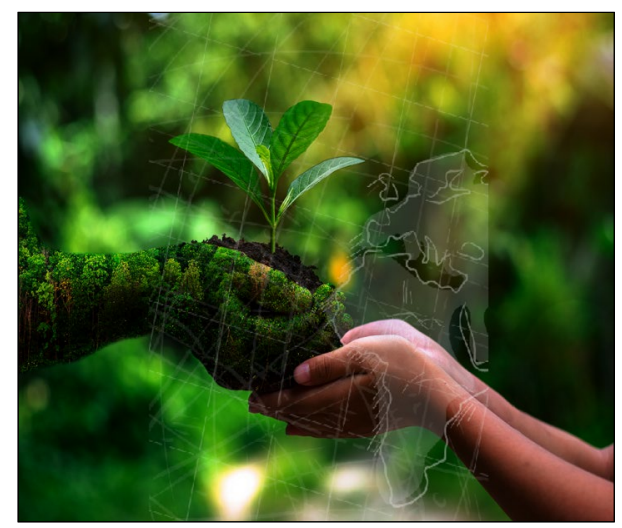

\title{
SUSTAINABLE URBAN DEVELOPMENT IN AFRICA
}

\author{
Gulelat Kebede
}

\section{Introduction}

Africa is urbanising fast and is largely driven by natural growth. ${ }^{2}$ Its population is young and growing. Historically, the urban transition took 100 to 150 years, but today's transition in developing countries occurs in about 30 years and is thus 'traumatic and disruptive' (Henderson, 2010). In the twenty years between 1995 and 2015, Africa's urban population nearly doubled and is projected to almost double again by 2035 (Barofsky, 2016).

Africa's urbanisation is not only rapid but is also taking place at a lower income level than the urbanisation history of other regions. A comparison with East Asia brings

1 With contributions from Ms Liz Paterson Gauntner, independent consultant, and Professor Josephine Musango, Stellenbosch University.

2 Natural growth rates of urbanisation in Africa and Asia are 3 percent and 1.7 percent respectively (UNECA, 2016). 
the point home. Africa is 40 percent urbanised with a per capita income of about $\$ 1000 .^{3}$ The figures for eastern Asia and Latin America are \$3 617 and \$1 860 when they reached the same level of urbanisation in 1994 and 1950 respectively. This reflects the relatively weak link between urbanisation and economic growth in Africa (Henderson \& Kritikos, 2017). Africa's rapid urbanisation is also taking place in a context of demographic transition, pressing environmental challenges and global technological revolution. A space-blind development approach is perilous, and the conventional sectorial approach is inadequate. In this chapter, we argue for a systemic approach that leverages urbanisation for sustainable development.

According to data from African Economic Outlook 2016: Sustainable Cities and Structural Transformation produced jointly by the African Development Bank (AfDB), the Organization for Economic Co-operation and Development (OECD) and the United Nations Development Programme (UNDP), two-thirds of the infrastructure needed by 2050 are not yet built (AfDB, OECD \& UNDP, 2016). Even with severe infrastructure deficit, African cities have already become the economic powerhouse of national economies; renewable energy is becoming increasingly cheaper and accessible; and Africa is endowed with natural resources as well as a youthful workforce that is educated and are literate in information technology (IT). These are some of the levers that underpin our argument for leveraging urbanisation for sustainability.

The chapter identifies urban resource consumption, spatial, housing, infrastructure and economic challenges and opportunities. It also highlights the policy issues related to these challenges and opportunities and closes with an illustrative list of relevant tools to support actions for transformative urbanisation.

\section{Sustainability through an urban lens: A systemic approach}

In 2001, The Economist portrayed Africa as 'hopeless continent', and a decade later, as a 'rising continent'. The port city of Onitsha (which elsewhere has been mentioned for its worst air pollution, slums or planning failure) was selected to portray Africa's cities as the economic powerhouse of 'rising Africa'. For the most part, the earlier African urban narrative emphasised the housing and infrastructure deficiency epitomised by growing slums. In recent times, a narrative that emphasises a growing 'middle class' and a potential youth dividend appears to be in vogue. Each perspective captures some truth but does not provide the full picture. African economies are multifaceted, as is the role of cities within them, and a more nuanced and systemic outlook is necessary to position urban Africa within its regional development agenda of economic transformation and sustainability.

3 All dollars (\$) are US dollars unless otherwise mentioned. 
An urban system is complex and, as illustrated in Figure 5.1, plays a key role in resource efficiency and sustainability.

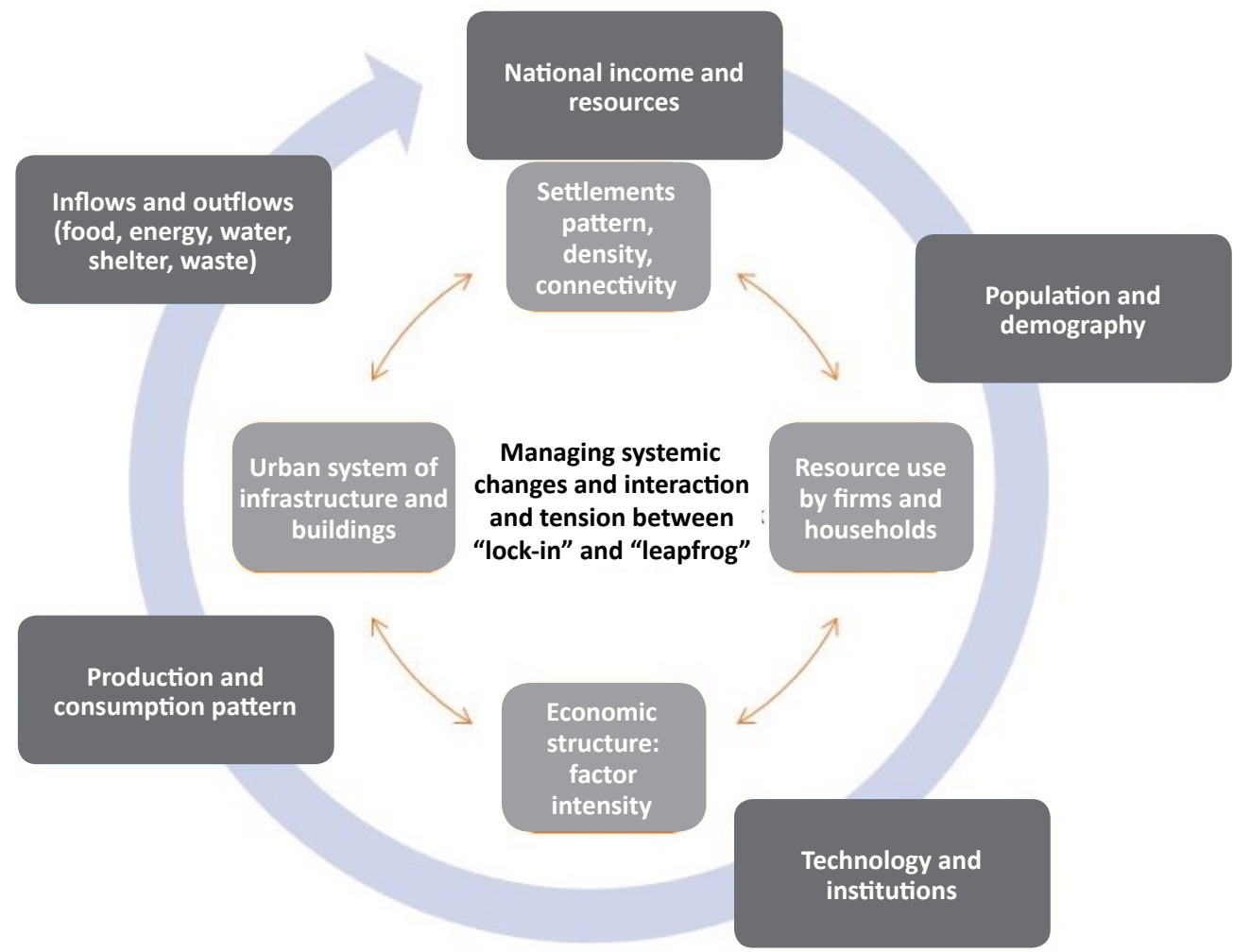

Figure 5.1 Forces shaping the sustainability of Africa's cities

At macro-level, as shown in the outer ring, demand for resources increase as the population grows and incomes rise. But the scale and intensity of demand for resources depend on the production and consumption patterns, which in turn depends on the way the economy is organised, technology is harnessed, and institutions are fashioned. As exhibited in the inner ring, resource consumption at city level depends on the size of the urban population on one hand, and the built environment on the other. The way urban streets are laid out and infrastructure is designed play a critical role.

If we consider cities as mega living organisms that consume resources and dispose of waste, their metabolic (in) efficiency hinges to a large extent on urban streets and infrastructure. Poor land use and transport systems that promote sprawl and fragmentation lock cities in unsustainable resource consumption. In contrast, smart planning and technology that capitalise on urban density and connectivity 
spur cities to sustainability. As depicted at the centre of the diagram, managing the forces shaping urban form is central to achieving urban sustainability. By adopting, environment-friendly urban and infrastructure planning and by harnessing technology, African countries have the opportunity to leverage urbanisation for sustainable development.

\section{The challenges and opportunities of urbanisation in Africa}

These are some key issues concerning the challenges and opportunities of urbanisation in Africa:

1. Urban Africa is well below the global average in resource consumption, although countries differ considerably. But for many countries, the low average per capita consumption is a reflection of resource deficiency. A growing urban population is under-serviced and do not have access to energy. Many African countries are experiencing rapid urban and economic growth trajectories and Africa's resource consumption and carbon emission are likely to increase in the following decades.

2. Africa's urban space is characterised by primacy, missing middle and rapidly growing small towns, a poor economic base, and limited job creation. The urban system is imbalanced, underperforming and unsustainable.

3. Prime cities are productive but feature premature diseconomies. The urban economy is dominated by informal and less productive economic activities. There has been poor job growth and manufacturing is largely absent, however, the role of non-industrial sectors including information and communications technology (ICT) and service appear to be growing.

4. Besides providing basic shelter, housing plays an important role in economic growth, job creation, wealth distribution and resource conservation. The housing price to income ratio in Africa is exceedingly high. Slums and informality are the default option for the majority. But as income grows, and if suitable policy conditions are created, demand for housing can unleash growth and drive resource efficiency.

5. Compared to other developing countries, Africa has a low level of infrastructure. The levels of investment needed to catch up are overwhelming. The impact of the deficit on economic growth and efficiency is significant. However, although most of Africa's infrastructure needs are yet to be met, Africa offers unique opportunities to choose sustainable infrastructure design options and harness smart technologies. 


\section{Resource consumption}

Based on data from satellite and aerial imagery, the growth of African cities has been characterised by fragmented or leapfrog urban development and unplanned expansion, with infill urban development accounting for a lower percentage of new urban development than in any other region except East Asia and the Pacific. Informality and peri-urbanisation, which drive urban sprawl and inequality, pose long-term challenges for the economy and the environment. Declining density and sprawl increase the costs of infrastructure. Between 2000 and 2014, African cities expanded their land coverage by an average of 4.08 percent. As shown in Figure 5.2, the average density of 16 of these cities declined by 2.48 percent, but with wide variation between cities (Lamson-Hall, Degroot, Martin, Tafesse \& Angel, 2015).

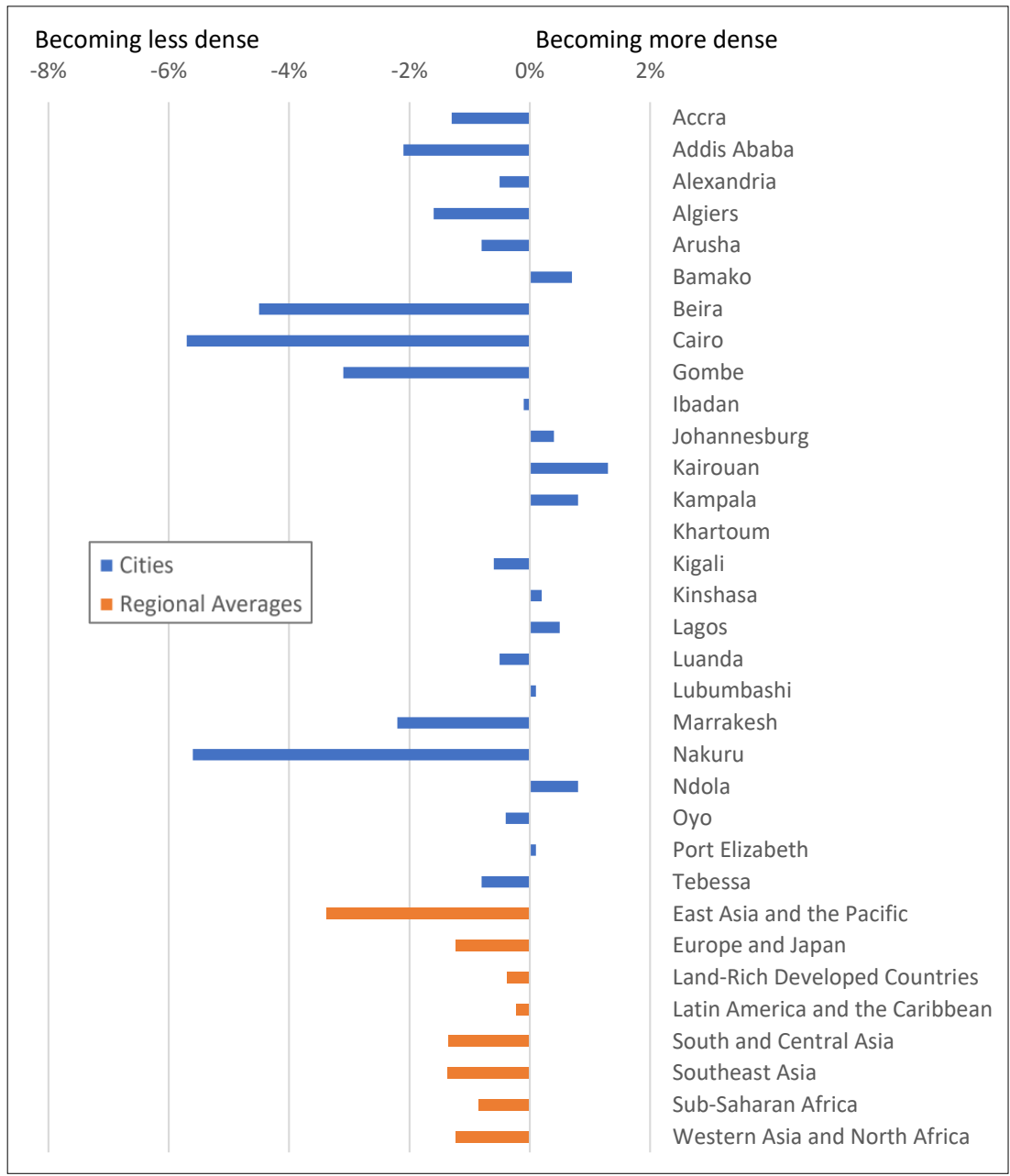

Figure 5.2 Percentage change in urban extent population density, ca. 2000 to ca. 2014: Cities and regional averages (Source: Data taken from Angel, Lamson-Hall, Madrid, Blei and Parent, 2016) 
Countries with better capacity and resources are not much better in managing sprawl. According to an article in The Economist, 'There are fewer people per square kilometre in Cape Town than in Woking, a commuter town in Surrey, England.' Considering a huge backlog in housing and urban services, and a rapidly growing urban population, demand for resources, including land, building materials, energy, food and water is expected to increase substantially in the coming decades.

Using national data and based on scaling relationships and country similarities in demographic, economic and climatic parameters, Currie and Musango (2017) have estimated resource consumption of 120 African cities and clustered them (Currie, 2015; Currie, Lay-Sleeper, Fernandez, Kim \& Musango, 2015). The key findings of their work carried out as part of a research on urban metabolism in Africa are summarised below (Currie, 2015; Currie \& Musango, 2017):

Of the 120 cities, 71 have per capita consumption levels below 8 tonnes; 38 cities exceed 10 tonnes per capita, of which only five are over 20 tonnes per capita. These consumption levels are below the average of the global North, but the low level of consumption largely reflects resource deficiency. 'On per capita basis, the average electricity consumption of Africa, excluding South Africa and North Africa, is $160 \mathrm{kWh}$ or 1.3 percent that of the United States' (United Nations Economic Commission for Africa [UNECA] et al., 2018:20).

Cities in northern and southern Africa - regions with higher per capita GDP and human development index - exhibit high per capita consumption. They may have to prioritise resource efficiency and resource access.

Cities of rapidly urbanising regions of eastern and western Africa are prominently missing from the list of relatively big resource consumers. Many of the cities in these regions will reach the range of $\$ 2000$ to $\$ 3000$ per capita, which is estimated as the global peaking point for emission intensity per unit of income (Stefanski, 2010). Further, the shift in the composition of GDP to non-agriculture urban sectors expected to accompany structural transformation in the coming decades will make African cities disposed to increased resource use and emission intensity. ${ }^{5}$

In the broader scheme of things, trends in energy consumption, mix and intensity will play critical roles in the urban and sustainability transition of Africa. Africa is rich in energy resources but poor in access to electricity. 'Only about a quarter of the population in Africa, excluding North Africa, has access

\footnotetext{
4 Tragedy of the commons, The Economist, 23 August 2018.

5 Change in structural transformation influences pollution intensity over time, and the initial effect is strictly positive (Stefanski, 2010).
} 
to electricity, versus about half in South Asia and more than 80 percent in Latin America, the Middle East and North Africa. Only 19 percent of the African population has access to clean cooking technologies - when excluding North Africa it drops to 14 percent,' (UNECA et al., 2018:20). Scaling up investment in electricity generation to outpace population increase is a big challenge, but the expanding possibilities to invest in renewables, which are cleaner and increasingly cheaper, is an opportunity. Currently, a third of the total primary demand in Africa is met by coal and oil. That means business-as-usual is not an option (UNECA et al., 2018).

The region also lags in energy efficiency. Though the average per capita energy consumption and carbon emission of Africa are low in comparison to developed economies or the world average, energy intensity levels remain significantly higher than the world average. In 2015, at 7.9mJ/US\$ 2011 PPP GDP, Africa, excluding North Africa, recorded an exceptionally high energy intensity. Compared to the OECD average of $4.5 \mathrm{~mJ} / \mathrm{US} \$ 2011$ PPP GDP, this amounts to 73 percent higher. In fact, with an average of $10.5 \mathrm{~mJ}$ intensity, a unit of output in low-income African countries consumes about 134 percent more energy than that of OECD countries. (UNECA et al., 2018).

Resource and energy consumption increase with economic growth. However, as shown in Figure 5.3, the correlation is not simple and linear. An array of structural factors including climate, affordability and density affect resource efficiency. Economic structure and urban form play critical roles in determining the scale and intensity of resource consumption. 


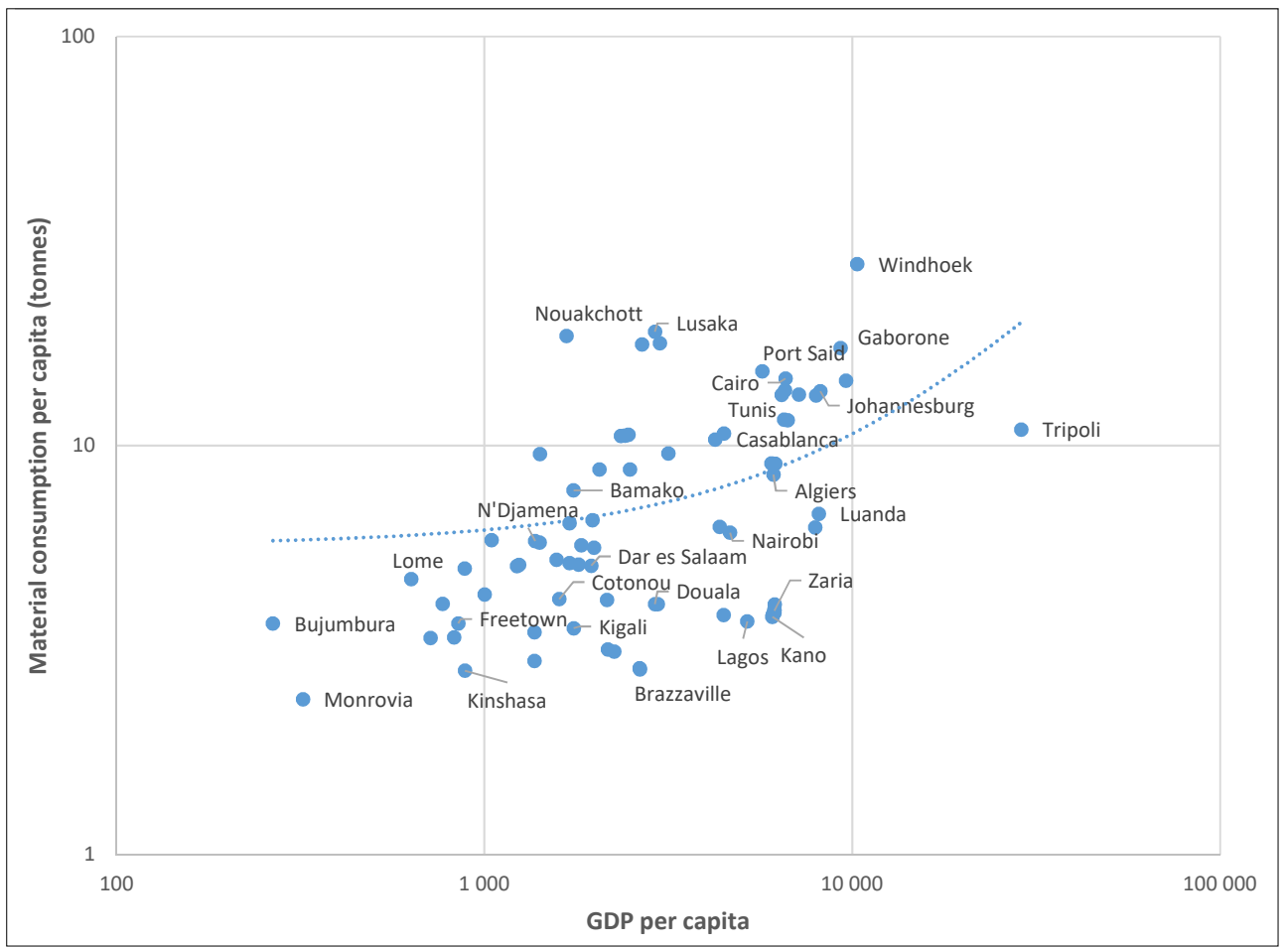

Figure 5.3 Material consumption and GDP in selected African cities, 2010

(Source: Data taken from Currie and Musango, 2017; World Bank, 2019)

\section{Spatial challenges and opportunities}

Africa is urbanising at a rate faster than historical trends, and with and without economic growth. The contrast between the urbanisation of resource-poor Africa and that of rich and industrial Europe is remarkable (see Figure 5.4). This is borne out by the following extract:

In Europe, urbanisation accelerated with the advent of the Industrial Revolution, rising from 15 percent in 1800 to 40 percent in 1910. Both Africa and Asia reached the same rate in half the time, moving from 15 percent in 1950 to 40 percent in 2010. (Jedwab, Christiaensen \& Gindelsky, 2014:1)

The challenge is that urban planning and investment has lagged urban growth for decades in Africa, resulting in chaotic urbanisation characterised by primacy, growing slums and informality. Crowding and premature diseconomies are constraining Africa's largest cities, while secondary cities and small towns are failing to keep up economically. 
Prime cities in Africa are an economic powerhouse. The 69 largest cities selected from 36 countries for a study on 'climate economy' in Africa contribute 36 percent of the combined national GDP while representing only 16 percent of the population (Godfrey \& Zhao, 2015). However, Africa's largest cities are facing several factors constraining their full potential. Drawing on a World Bank survey of firms, in 188 subnational locations of 45 African countries, a recent UNECA report concludes that due to weak infrastructure, first and foremost, because of constraints in electricity and transportation, African cities with a population over 1 million are underperforming. They are also hampered by institutional barriers, including inadequate density, artificial separation and rigid land uses, and residential segregation (UNECA, 2017a). Improving these institutional barriers and infrastructure constraints, if implemented within a smart and inclusive growth framework, can yield economic growth and productivity and contribute to job creation and resource efficiency.

Unfortunately, because of poor infrastructure and weak institutions, smaller cities also appear to be impacted by congestion and overcrowding, while lacking a strong economic base for sustainable growth and job creation. The result is an excessive concentration of urban populations into a single large city, which could 'detract from national income growth as resources are squandered in oversized congested cities' (Henderson \& Kritikos, 2017:23).

Moreover, intermediate cities, which play a critical role in facilitating the development of specialised industries and linkages between small and big cities, are not growing as much. Henderson and Kriticos maintain that:

smaller cities near the bottom of the size distribution tend to be growing faster than larger secondary (but not primate) cities and seem to exist to serve agriculture and to house farmers - with their fortunes perhaps rising with improved productivity in farming in recent years. (Henderson \& Kriticos, 2017:31) 


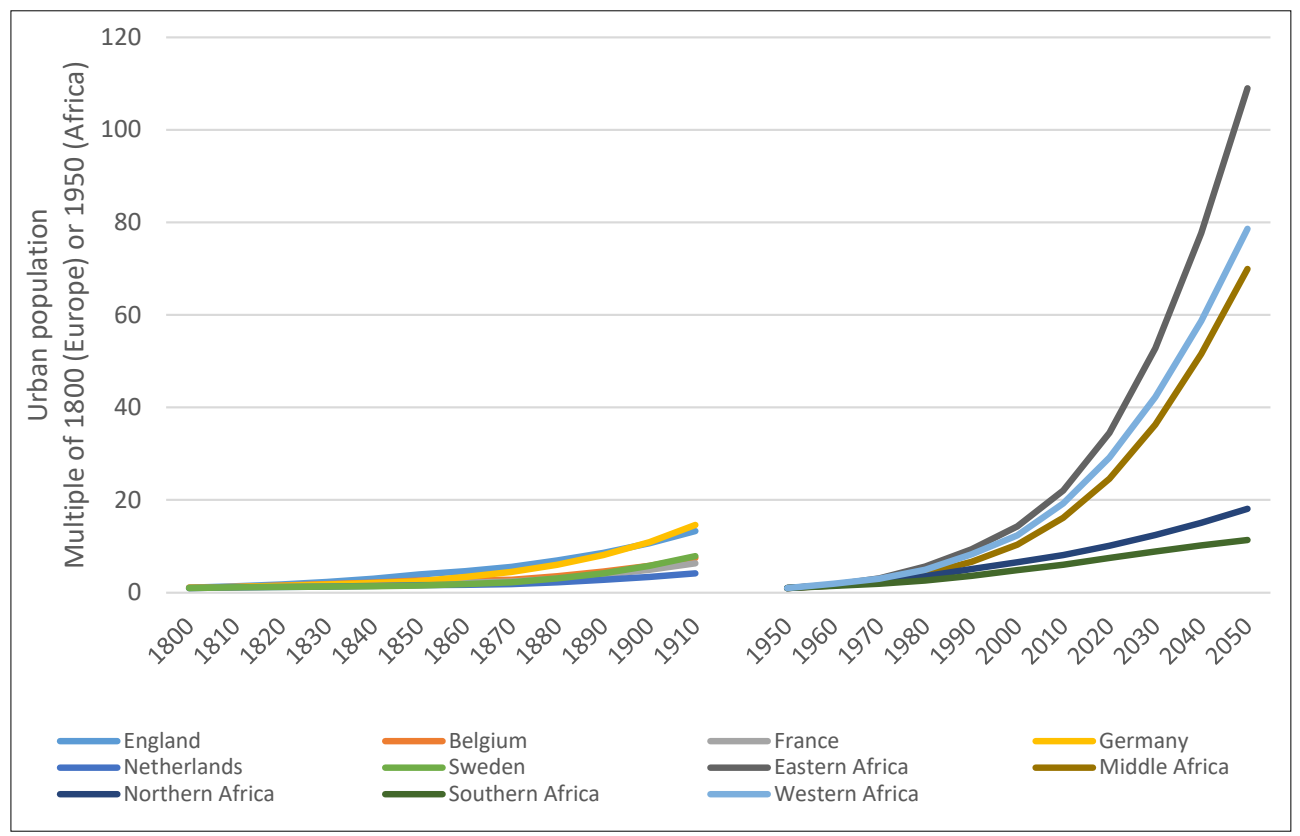

Figure 5.4 Urban population increase in selected European countries, 1800-1910 and African regions, 1950-2050 (Source: Data taken from Jedwab et al., 2014; United Nations Department of Economic and Social Affairs [UNDESA], 2018)

\section{Housing challenges and opportunities}

Housing is the engine of economic growth and social and economic wellbeing. The Asian countries of Hong Kong, Singapore, South Korea and Taiwan have used homeownership to boost economic growth, employment and government revenue. In Hong Kong, the property sector contributed about 24 percent to GDP and 7 percent of the labour force in the1980s and 1990s. In Singapore in the 1980s and 1990s, 15 percent of expenditure was allocated to housing. This was in line with the government's initiative of the 'Home Ownership for the People Scheme' established in 1964. In developing countries, 3-8 percent of GDP originates from the construction sector, and housing constitutes over a third of it. The estimates go higher if informal housing activities and their multiplier effect are considered (Harris \& Arku, 2006).

Besides these economic and social benefits, housing, through efficient use of building materials and energy, can deliver a huge environmental dividend and improve the living conditions of millions. But at low-income levels, the majority in many African countries cannot afford even the cheapest housing unit.

Housing is 55 percent more expensive in urban Africa than in other developing countries of similar income levels. The typical housing price-to-income ratio in 
Africa is over 10:1, compared to the global range of $3: 1$ to $5: 1$. This is way above the affordable rate, even for those with a stable job and income in the public service or the formal private sector. This signals a serious structural problem associated with the key components of housing provision: urban land, building materials and construction, and housing finance (UNECA, 2017a).

Spending on housing typically begins to increase after the per capita income level of $\$ 3000$ (World Bank, 2015), which suggests investment in housing is expected to grow significantly in the coming decades as countries continue urbanising and become middle-income. This is a huge opportunity to spur inclusive growth and nudge urbanisation on a path to resource efficiency. Because of its small housing stock and limited lock-in forces, Africa can reap huge social, economic and environmental benefits while contributing to a reduction of global carbon emission, ${ }^{6}$ from its massive future investments in housing by promoting affordable and green building solutions.

\section{Infrastructure challenges and opportunities}

Urban Africa suffers a huge infrastructure deficit. 'The region lags behind the rest of the world in access to electricity, internet penetration and access to improved water, and has large road maintenance needs' (UNECA, 2017a:126). The World Bank estimates the annual investment need of Africa for infrastructure at $\$ 93$ billion, or approximately 15 percent of regional GDP (Foster \& Briceño-Garmendia, 2010). ${ }^{7}$ Annual national public spending on infrastructure is exceedingly low with an average of 2 percent of GDP in 2009-2015, compared to 5.2 percent in India and 8.8 percent in China (Muggah \& Hill, 2018).

The situation with electricity captures the essence of infrastructure deficiency. World development indicators show that in sub-Saharan Africa, less than half of the citizens have access to electricity, compared with 85 percent in low- and middleincome countries as a whole (World Bank, 2019). Power outages are a serious problem forcing firms to install back-up generators. It is estimated that formal and informal firms lose 6 percent and 16 percent of their sales respectively (Foster \& Briceño-Garmendia, 2010). It is also estimated that the outages result in a loss of 2.5 percent of GDP to the economy, ranging from 1 percent in Niger to 4 percent in Tanzania (Eberhard, Rosnes, Shkaratan \& Vennemo, 2011).

6 Cement-making and the production of steel, half of which goes to building, account for 14 percent of worlds' carbon emission (The house made of wood, The Economist, 5 January 2019).

7 Yet, at 2 percent of GDP, public spending on infrastructure is exceedingly low, resulting in a 40 percent decline in firm productivity and slums (Muggah \& Hill, 2018). 
Besides its impact on economic productivity, urban infrastructure investment, when done cleverly, can also be a game-changer. Two-thirds of investment in African urban infrastructure needed by 2050 is yet to be made (Muggah \& Hill, 2018) and three-fourths of urban areas and infrastructure needed by 2040 in Uganda, for example, is yet to be built (UNECA, 2017a). Twice as much as the existing infrastructure has to be built in one-third of the time the existing infrastructure was built (Collier, 2016).

Urban concentration lowers the unit cost of piped water, sewers and drains, and public services, however, these benefits come with challenges. Cities rely on infrastructure for the regular flow of ecological services and natural resources (food, water and biomass) needed to support urban life and economy, and thus its disruption through natural forces or due to climate change poses huge social and economic risks. Choices of urban form and infrastructure technologies and systems determine whether these risks are mitigated or exacerbated. Bad choices in urban and infrastructure systems not only increase future environmental risks, often with a higher burden on the urban poor, but also inhibit or distort productive resource use or consumption, thus exacting penalties on economic growth and efficiency.

\section{Economic challenges and opportunities}

Though many African countries have seen strong economic growth in the last two decades, for the most part, growth has been jobless.

African cities lack strong economic bases. A study that investigated sector level employment data by city size distribution (prime, secondary, tertiary, small) of 11 African countries (Ethiopia, Tanzania, Uganda, Mozambique, Ghana, Cameroon, Mali, Malawi, Zambia, Sierra Leone and Liberia) covering a population of 242 million (of which 62 million were urban) concluded that (i) over 40 percent of urban residents in the second quartile and bottom half of cities are engaged in agriculture; (ii) manufacturing and tradeable services (finance, insurance, real estate and business services) in prime and secondary cities are only around 10 to 12 percent, much lower than their agglomeration opportunities suggest; and (iii) housing and servicing ('trade') farmers are the chief economic drivers in the bottom 75 percentile of the cities and even in the upper 25 percentile of the cities outside prime cities (Henderson \& Kriticos, 2017).

This, in major part, reflects the slow or weak structural transformation characterising African economies. Structural change, or the movement of labour from low-productivity sectors to higher productivity sectors, typically accompanies urbanisation and is part of the economic development process. However, African 
countries have seen labour shifting into urban informal and non-tradeable sectors with low productivity, while the expansion of manufacturing and tradeable services has not kept pace with urban population growth. Though there have been some positive signs in structural change in recent years, the overall change does not mark a turning point. On the contrary, the decline in the share of manufacturing from 10.6 to 8.4 percent between 2000 and 2015 and the stubbornly high informality is troubling. Africa's urban middle class is expanding, but so are the number of Africa's urban poor (UNECA, 2017a).

The above discussion points to the need for Africa to consider an alternative path for structural transformation. Developing on the back of the export-oriented manufacturing sector, as East Asia did, may not be a viable option for all countries. Some suggest that African countries should pursue industries without smokestacks, such as tradeable services, agro-industries, horticulture and agro-business, communication technology-based services and tourism. Some signs may support this proposition. Between 2000 and 2015, Africa's service sectors' share grew from 44 percent to 55.7 percent; a leap by a historical measure. According to Newfarmer, Page and Tarp:

Service exports from Africa grew more than six times faster than merchandise exports between 1998 and 2015. In Kenya, Rwanda, Senegal, and South Africa, the ICT sector is flourishing. In Rwanda, tourism is now the single largest export activity, accounting for about 30 percent of total exports. Ethiopia, Ghana, Kenya, and Senegal are all integrated into global horticultural value chains, and Ethiopia has become a leading player in global flower exports. (Newfarmer, Page \& Tarp, 2018:66)

Some of the recent revision of GDP figures following the rebasing that took place in a few African countries like Ghana, Kenya and Nigeria reflect the increasing contributions of the service industry including ICT, media and entertainment in the economy (Sy, 2015).

The role of ICT is of particular relevance for Africa. At 26 percent, mobile internet penetration is low, but it is expected to contribute $\$ 110$ billion, or the equivalent of 7.7 percent of GDP and employ approximately 3.5 million people in 2016 . Penetration is expected to reach 40 percent in 2020, indicating a growing potential to accelerate leapfrog growth and transformation (Rogers \& Pedros, 2017). Venture capital, which reached a $\$ 1$ billion from a modest start of $\$ 40$ million in 2012 , supports African entrepreneurs starting up tech sector businesses across the region, including in Ghana, Kenya, Nigeria, Rwanda and South Africa, which is a promising sign. Some estimate that 3500 new tech-related ventures and 200 innovation hubs are in existence. 
Prime cities will continue to be important economic drivers, particularly in the case of the high-end service sector, innovation and knowledge areas, however, the emerging digital economy and service economy in large part favours economic dispersion across secondary, tertiary and small cities.

\section{Key policy and strategic issues for African countries}

This section explores some policy and strategic issues concerning African countries.

\section{Key points}

These are a few key points regarding policy and strategic issues concerning African countries:

There is room to improve the absorptive capacity and functioning of prime cities, but this can only succeed if implemented within a policy framework of creating a balanced system of cities and human settlements.

Making urbanisation a transformative force for economic development and sustainability requires promoting distributed economies across the continuum of human settlements. Digitisation, green and industrial revolutions can be harnessed for leapfrogging.

The housing issue in Africa is not merely lack of it, but affordability. Investments in housing that are not connected to jobs and amenities or implemented outside an integrated planning framework are not effective or sustainable.

Africa is infrastructure deficient and narrowing the gap in infrastructure is a key success factor in Africa's race to catch-up economically. As the majority of infrastructure in African cities is yet to be met, there is the opportunity to reap sustainability dividend by adapting compact and dense urban form and by shifting to cheaper and cleaner energy. Moving to smart urban infrastructure design and technology can be a game-changer.

The urban policy and strategy issues critical to sustainability transition in Africa are centred on four themes: the spatial characteristics of cities, housing, infrastructure and productive urban or local economies. They are interconnected. Figure 5.5 highlights major policy issues involved within each policy theme. 


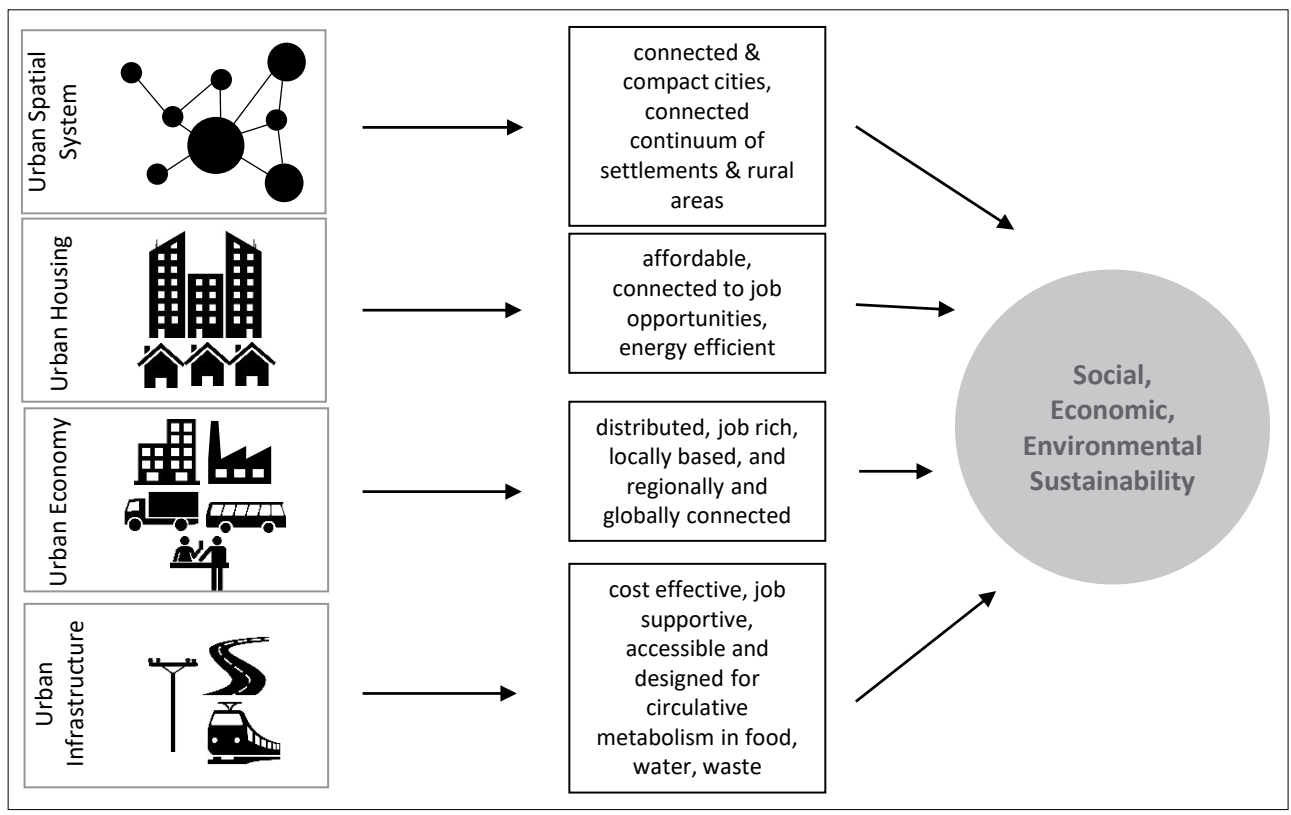

Figure 5.5 Themes and policy issues for the sustainability of Africa's cities

Countries vary substantially in the level and rate of urbanisation and income and differ in resource endowment (see Figure 5.6). They also vary in institutions and policy thus GDP is not a sole predictor of outcomes in sustainability. ${ }^{8}$ Policy issues and outcomes are context-specific. We are not here proposing an all-size-fit silver bullet but outline the broad principles and themes that are universally relevant to the shift to sustainability-oriented 'leapfrog' development advocated in this book. 


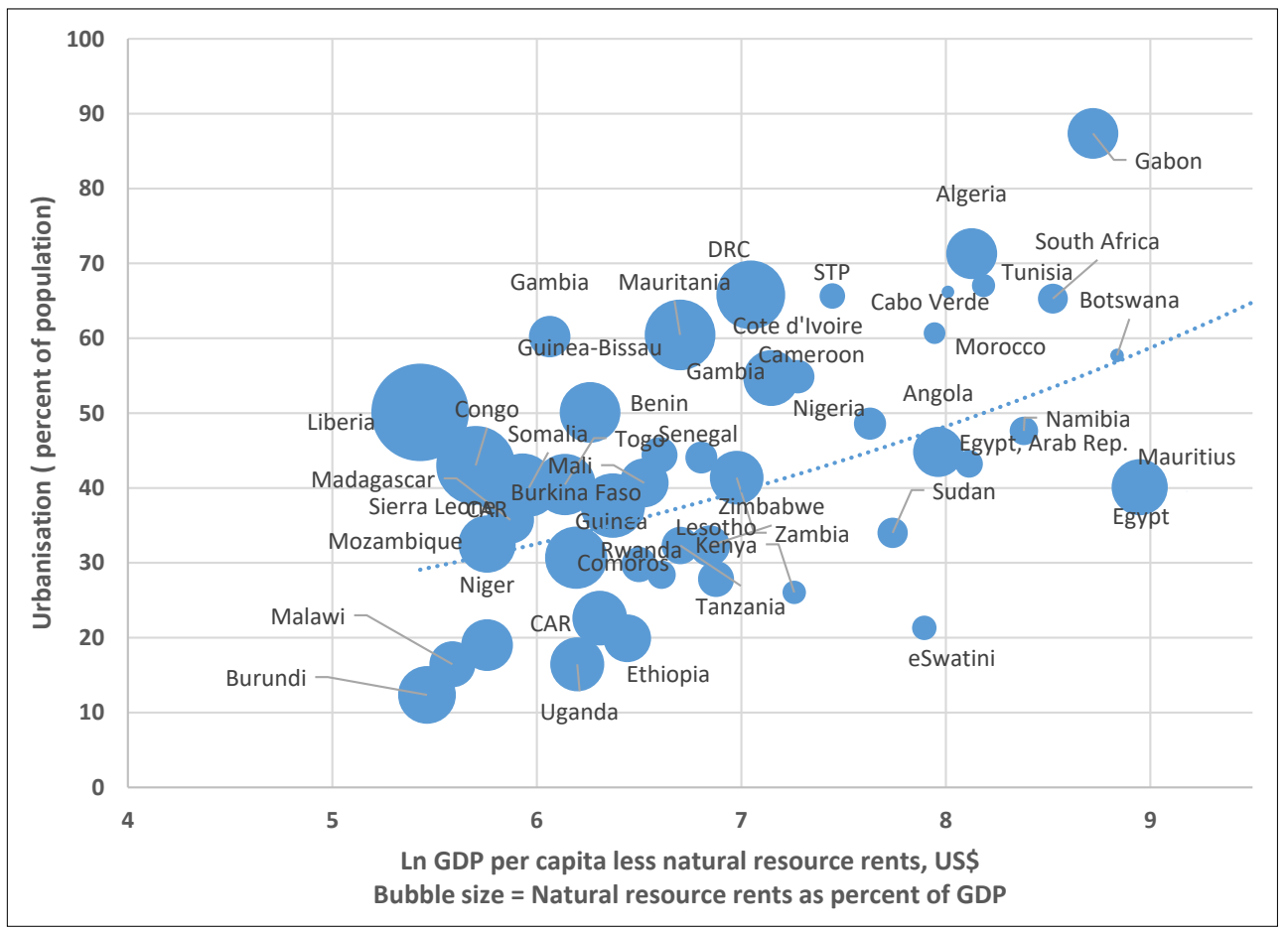

Figure 5.6 Income, urbanisation and natural resource rents, 2016 (Source: Data taken from development indicators, World Bank, 2019)

\section{Spatial characteristics: Promoting compact, connected development across the continuum of settlements}

Urban growth in many African cities is fragmented and patchy with a flat or declining density. The growth is characterised by the rapid peri-urban expansion that concentrates the poor on the urban fringes with limited or no access to the job market and basic services. This growth is characterised by poor planning and inefficient land use on the one hand and rapid urbanisation, migration, driving sprawl and congestion on the other, especially in the low-income rapidly urbanising countries. If unchecked, the trend can harm economic and resource efficiency, and in many cases result in premature diseconomies.

There is room for improving the absorptive capacity and functioning of prime cities, but this can succeed only if implemented within a policy framework of creating a balanced system of cities and human settlements. The majority of urban populations live in small cities and towns but lack basic services and job opportunities, while those in prime cities struggle to survive in the informal economy. Thus, improving urban productivity in prime cities is a policy priority, but is also inadequate. A balanced system of cities involves decentralising economic 
activities and connecting villages, towns and cities across the human settlements continuum and Africa has a long way to go in this direction. 'With a few exceptions, all countries below the Sahara have primacy rates above 30 percent and several above 50 percent (Henderson \& Kritikos, 2017:23).

Second-tier cities are weakly represented in the system of cities in Africa. According to Henderson and Kritikos:

The share of Africa's population in non-primate cities with over 1 million population is only 8.5 percent, while for all low- and middle-income countries it is 26 percent. Instead, Africa has a high concentration in cities under 300000 , as well as primate cities (with Africa at 28 percent versus all low and middle-income countries at 17 percent). (Henderson \& Kritikos, 2017:25)

Considering the role of large secondary cities in facilitating job creation and labour mobility from rural to urban economies, the missing middle in urban Africa is a concern (Christiaensen \& Todo, 2014). Secondary cities can be pivotal in industrial development. In Nigeria, for example, the recent growth in manufacturing has shown to be driven by its mid-size cities (Aba, Ilorin, Onitsha, Kaduna and Jos) spread across the different regions. This indicates a positive sign of urban differentiation along industrial functions (Bloch, Makarem, Yunusa, Papachristodoulou \& Crighton, 2015). Guiding such development through better urban and infrastructure design by considering the specialised needs of cities of different sizes and functions will have a long-term pay off in social, economic and environmental terms.

Though such forward-looking investment by countries in their urban future is generally constrained by resources, the gap appears to be fundamentally at the policy and planning levels. Across the region, it is not uncommon to see resource-intensive mega projects and industrial zones planned and implemented without adequate consideration of their urban and spatial implications (UNECA, 2017b). Though some countries, such as Ethiopia, Rwanda, and Uganda, have identified strategic secondary cities to help diversify the economy and advance balanced development, these are not always fully conceptualised or backed by strategic planning.

In low-income African economies with significant agriculture sectors fostering rural-urban linkages is most critical. The debate about the urban-rural divide is a recurring one, with some proposing a modular urban model where town-centred agro-political districts could be developed in densely populated rural and peri-urban areas to expand social and economic opportunities and tame or slow migration to cities (Friedman, 1996). Neither the sole focus on agglomeration economies nor the utopia of rural cities is realistic. Considering the large employment and 
output share of agriculture and the realities of circular migration (of back-and-forth movement of people between cities and rural areas) observed in Africa, ${ }^{9}$ fostering the links between urban and rural economies is not an option but a priority.

Small market towns will be crucial in fostering urban-rural linkages. A study that simulated urbanisation in Ethiopia and Uganda concluded that reallocation of public investment from cities and (rural areas) to towns leads to faster poverty reduction, underscoring the role of small cities in facilitating these linkages and their impact on income (Dorosh \& Thurlow, 2014).

\section{Housing: Promoting affordability and resource efficiency}

Because the majority of cities and/or their housing stock is yet to be built in Africa, housing is potentially a major economic and resource efficiency driver but is constrained by structural impediments. Policy priorities include scale, resource efficiency and affordability.

The share of the population with discretionary spending above the threshold for decent housing in low-income and/or less urbanised countries is very small. These countries may have to prioritise slum reduction and nonconventional affordable housing options, including rental housing, while building the necessary conditions (land, building regulations, competitive construction industry and housing finance) for the housing and real estate sector to flourish. The housing issue in Africa is not merely the lack of housing, but affordability. Based on typical rental rates in African cities, some estimate a housing cost of $\$ 15000$ long-term loan interest and principal of $\$ 500-\$ 800$ a year as affordable to informal housing occupants. However, this is a far cry from reality (Collier \& Venables, 2014).

Land use regulations and building standards play an important role in shaping affordability. Existing building standards, such as wall thickness, room size, depth of foundations, and regulation of minimum lot size, if improved, can also help affordability. The minimum legal plot size in of Nairobi and Dar es Salaam is, for example, one-sixteenth of an acre and 500 square meters respectively, which is unaffordable to ordinary households (Collier \& Venables, 2014).

Technology is also part of the solution. It is estimated that implementing smart building solutions could save as much as 30 percent of water usage, 40 percent of energy usage and reduce overall building maintenance costs by 10 to 30 percent (Honeywell \& Ernst and Young, 2015). There are alternative technologies and housing solutions that may be applicable even to slum upgrading. The 'smart

9 Migration to rural areas has been observed in countries like Zambia in the 1980s and Côte d'Ivoire and Mali in the 1990s, perhaps reflecting some level of 'counter urbanisation' caused by the economic hardship of the urban poor (Potts, 2009). 
shack' design in South Africa, which resulted from the collaboration between city authorities and a local university, is an example (Modisaatsone, 2014).

Often innovation and technology precede changes in institutions and regulations. However, low-income countries can reverse this by moving to progressive building code and planning practices in phases to take advantage of existing and in pipe technology and know-how in energy-efficient housing solutions. In the middleincome countries, the resource efficiency gains will come from new units and from retrofitting of the existing stock. These countries also have a better capacity to invest in innovative housing designs and improvement of building materials.

In countries where the majority of the population has reached a disposable income threshold and can afford the most basic shelter, the role of government should focus on creating a policy environment that encourages research and investment into affordable and resource-efficient housing options and innovations, and not on building housing units themselves. Innovations can come from local or global sources, but their uptake depends on the policy and the institutional environment. Indigenous or local knowledge of nature-friendly housing solutions can be rediscovered, improved and standardised. Pipeline technologies on building design and construction materials (cement, steel, wood) can be learned and adapted.

The prevalence of slums and informality in African cities is to some extent symptomatic of a disconnect between planning, infrastructure and housing. The current default order of housing, infrastructure and planning should be reversed to planning, infrastructure and housing (World Bank, 2015). Studies show that if the land is efficiently laid out, housing and service provision can be incrementally improved, at much less cost than retrofitting slums. Slum upgrading could cost up to 12 times more, compared to service provision in areas with sub-divided plots and blocks (Campbell, 2018). There are huge cost savings to be gained from guided urbanisation, especially for low-income rapidly urbanising countries, if settlement formation is preceded by basic planning and followed by phased investment. Middle-income countries devoting big public grants and subsidies to mega housing projects should watch the unintended consequences these projects may have, for example, on urban sprawl.

In the end, housing is a core component of good urban planning and implementation. Housing without proper planning, infrastructure and jobs, is ineffectual and spatially inefficient. The majority of urban residents in African cities live in slums, signifying the prevalent problem of 'people without housing. But the world, including Africa, is also replete with examples of 'housing without people' where houses were built but not occupied because of planning flaws, wrong locations or a lack of jobs and opportunities. This is a clear indication of squandered resources 
due to a lack of coherent policy and proper planning. It is not uncommon for subsidised mass housing projects and associated infrastructure investment targeting development on the urban edge to end up driving urban sprawl. Though cheaper land on the periphery may be the key factor driving such development, the longterm overall cost to the city resources could be much higher than anticipated. The anomaly of 'housing without people' and the problem of 'people without housing' observed in many cities are symptomatic of fundamental urban development flaws and resource inefficiencies that should be prevented or mitigated.

\section{Infrastructure and urban services: Promoting resource efficiency and access to services}

There is no question that African countries need to step up their efforts in infrastructure investment to meet the pent-up and growing demand and accelerate growth. ${ }^{10}$ Estimates suggest Africa could increase its annual GDP growth by 1.7 percent, 2.2 percent and 2.6 percent if it could close its infrastructure gap with other developing regions, Mauritius (with the region's best infrastructure) or East Asian economies respectively (Calderón, 2009). Accounting for efficiency gains, Foster and Briceño-Garmendia (2010) estimate the funding gap of Africa at $\$ 31$ billion per year after accounting for potential efficiency gains. AfDB (2018) estimates the range between $\$ 68$ billion and $\$ 108$ billion. The funding needs of low-income, middle-income and resource-rich countries are estimated at 23 percent, 10 percent and 12 percent of GDP respectively (Foster \& BriceñoGarmendia, 2010). ${ }^{11}$ Urban infrastructure covers both urban-specific public utilities and services and productive infrastructure, such as energy generation and railways and highways that are national in coverage but critical to the functioning of the urban system, and are thus difficult to categorize and estimate with precision. But assuming $1 / 3$ of the total investment to be urban, the investment gap for African cities could be anywhere between $\$ 36$ billion and $\$ 59$ billion (AfDB, 2018; Oxford Economics, 2017).

10 Countries that have achieved and sustained high economic growth had 25 percent or more of investment rate and additional investment of 7 to 8 percent of GDP in education, training and health (Commission on Growth and Development, 2008).

11 Given the backlog, population growth and economic realities, plugging the gap in infrastructure is a long-term undertaking. African countries may not have the luxury of building infrastructure first before economic activities, thus the most realistic scenario of development is one of strategic investments in key bottlenecks along with massive smallscale bottom-up investments. But for this two-prong approach to work, clear principles and standards of sustainability, efficiency and equity have to be mainstreamed to guide prioritisation, planning, financing and implementation of infrastructure investment. 
But an increasing investment is one side of the problem. The way infrastructure is designed and provided will impact urban quality and sustainability, thus the policy issues involved with infrastructure and services are not simply about how to finance the gap, but how to ensure accessibility and achieve resource efficiency. Based on a study of 45 countries throughout 2000-2015, The IMF suggests that investment efficiency in sub-Saharan Africa can be increased by 35 percent (Barhoumi, Vu, Towfighian \& Maino, 2018:4). There is room for improvement in project preparation and implementation. Coordination across sectors and levels of government, along all elements of the project cycle, is particularly important in the case of urban infrastructure.

At a more fundamental level, three issues are critical. Firstly, urban form and design determine the nature and configuration of infrastructure. The built environment of today's cities is the product of urban vision and design implemented generations ago; the lock-in effect of urban form is long-lasting. Secondly, considering severe resource scarcity and the long life cycle of infrastructure, project prioritisation should be considered within a strategic framework. Estimates on the return of investment in hard infrastructure give electricity generation and connectivity infrastructure the top ranking. But even within energy or connectivity sectors, there are multiple decision issues that matter, such as choice of technology or energy mix, or scale and location. Finally, in the context of sustainability transition, part of the investment decisions involve shifting to new technologies or future technologies. However, policy inertia and powerful stakeholder interest, if not countered, could hamper technological shift and increase the stock of 'stranded capital. This would make 'leapfrog' transformation increasingly difficult or costly.

The majority of infrastructure investment in low-income and less urbanised countries is yet to happen. But if sound principles of urban design and sustainability are applied, it can provide major environmental, social and economic co-benefits. Dense, compact, desegregated and connected cities are resource efficient, inclusive and productive. Urban metabolic processes - the way food, energy, water and raw materials are conveyed and consumed by households and firms, and the way air pollution, waste and sewage are disposed or recovered - have major economic, social and environmental implications. The way infrastructure is configured and managed determines the nature and size of these implications. In addition, middleincome countries, in particular, can benefit from infrastructure maintenance and rehabilitation and so reap the resource efficiency dividend accruing from good infrastructure planning and design.

A dense urban form helps to reduce the cost of network infrastructure - one of the underlying benefits of big cities. But beyond a certain size, the cost of congestion weighs more than the benefits of density. In the context of Africa, the 
urban poor, due to limited access and coverage, resort to costly alternatives, while prime and large cities, due to poor planning and investment in infrastructure, prematurely experience resource inefficiency and diseconomies. The results harm both the economy and the urban poor and are unsustainable. African cities are expensive and infrastructure services are twice as expensive (Foster \& BriceñoGarmendia, 2010:4).

This makes optimising the trade-offs between density, congestion and decentralisation of urban services important. There are efficiency gains from existing infrastructure, by consolidating where development is fragmented and by improving urban layout and density. But improving access and coverage in Africa, especially in low-income countries, and mitigating and reversing primacy, is untenable without a concerted effort to decentralise basic urban services. The balancing act of these forces - harnessing agglomerations and decentralising urban services - requires careful consideration of different or alternative urbanisation models and their cost implications within a long-term national development plan.

At the city and metropolitan scale, African countries, especially rapidly urbanising low-income countries, should prepare urban expansion plans while they still have time to do it. Land use and supply is a cross-cutting policy issue affecting planning, housing and infrastructure. Failing to secure public land for trunk infrastructure and transport rights of way pose a barrier to infrastructure investment and causes investment costs to escalate. Given the severe resource constraints they face, lowincome African countries may not have the necessary cash to invest immediately, but by putting land, basic infrastructure and necessary regulations in place, they can signal the direction to the private sector and slowly steer development to a sustainable path.

Investing in new cities is an option, especially for resource-rich countries, but the experience so far is not very positive. New cities are costly and take decades to complete. More importantly, unless, designed and developed on the basis of a new economic and environmental vision, they may not be much different from existing cities. Decisions on new cities should be based on rigorous analysis of alternatives, including urban expansion and infill development of existing cities, and sustainability should be an overriding criterion.

Technology in renewable energy, mobility, and ICT offers new opportunities for 'latecomer' Africa to leapfrog. In the case of high-income countries, economic viability considerations and the existence of large stocks of capital from older technologies may warrant a delay of investment in new technologies. But for rapidly urbanising low-income Africa, this is less applicable, since the forgone output, jobs and income due to energy scarcity, for example, is very high, while the stock of 
existing capital and technology is relatively small. Governments, individually and collectively, should adopt policy actions to improve the supply of capital and skills that complement and change relative prices in favour of future technologies to accelerate growth now, while reducing the cost of a future lock-in by fast-tracking the transition to sustainable options. ${ }^{12}$

The emerging technology for mini-grid and decentralised energy system is particularly important in the context of small cities and rural towns. Information technology applications and penetration hold promise for expanding access to urban services, even to remote rural areas and market towns. Middle-income resource-rich countries or countries with a promising economic growth trajectory can step up investment in smart cities or integrated smart systems to improve urban management and resource efficiency. How much these opportunities are to be exploited depend on institutional capacity and socio-technical conditions. Further, in the African context, technological and infrastructure transitions need to consider the co-existence of alternative solutions and heterogeneous socio-technical systems (Silver \& Marvin, 2017).

Reversing subsidies to the carbon economy, especially in resource-rich countries should be a policy priority. Governments spend $\$ 21$ billion in fuel subsidies, notably in North Africa, Angola and Nigeria, straining the public budget, disincentivising investment in renewable energy and creating carbon-based stranded assets. Rechannelling subsidies to renewables can accelerate the adoption of renewable energy. The cost of renewables is declining fast and becoming competitive and affordable. According to the International Energy Agency (IEA), 'compared with typical per kWh costs of $\$ 0.08$ for large-scale hydropower, $\$ 0.10$ for geothermal, and $\$ 0.07$ to $\$ 0.14$ for natural gas' (Avila, Carvallo, Shaw \& Kammen, 2017).

Low-income and rapidly urbanising countries will generate long-term co-benefits by investing in public transport systems that better connect workers and firms. In anticipation of long-term transport needs that accompany rapid urbanisation, African countries should leverage current urban planning and infrastructure investment to support future electrification of public transportation as well as integrating grid-edge technologies (UNECA et al., 2018). Middle-income countries can use investment in transport infrastructure to remedy poor planning legacies that may have disfranchised and segregated the urban poor. Also, these countries can improve efficiency and access to the urban poor by integrating urban services and by better targeting subsidies.

12 For a detailed review of the policy trade-offs associated with green technologies facing Africa, see Paul Collier and Anthony J. Venables, Greening Africa? Technologies, Endowments and the Latecomer Effect (Collier \& Venables, 2012). 


\section{Productive and inclusive economy: Job creation and structural change for sustainability}

The success of urbanisation as a transformative force fundamentally hinges on the ability of African countries to leverage urban advantages for job-rich growth and structural change. Understanding the links between economic and spatial development is the starting point. Urban settlements are the indirect outcome of many policies interaction with economic agents who must make locational decisions (Hamer \& Linn, 1987). Macroeconomic policies and sector priorities have stronger spatial impacts than urban policies, per se. Prevailing economic structures influence the economic geography of infrastructure and the relative intensity of capital, energy and labour, and thus impact on resource efficiency and job creation simultaneously. Alignment between spatial, infrastructure and economic sector planning is the key to sustainable urban development.

Despite some positive signs of structural change since 2000, manufacturing has been largely been absent and growth has not been job-rich. Africa's employment share of manufacturing and productivity in industry and services are one-third and one-half that of Asia respectively (World Bank, 2013). Some economies are resource-reliant and locked in energy- or capital-intensive economic structure. This crowds out labour-intensive sectors and hampers economic diversification and the creation of employment. Past trends suggest continuing high labour-force growth, a slow movement of output and employment into manufacturing, and slow expansion of tradeable sectors (Fox, Thomas \& Haines, 2017). Informality remains high and the impact of the recent GDP growth on the share of vulnerable employment has been negligible (see Figure 5.7). This suggests a need for deliberate policies to make growth job-rich and inclusive and to explore the potential of 'non-smokestack' industry and tradeable service sectors as alternative paths for structural change. ${ }^{13}$

13 In recent times, researchers have suggested, with the right policy and institutional environment, non-smokestack industries including tradeable services, agro-industry, horticulture and tourism could be potential drivers of structural transformation in Africa (Coulibaly, 2019). 


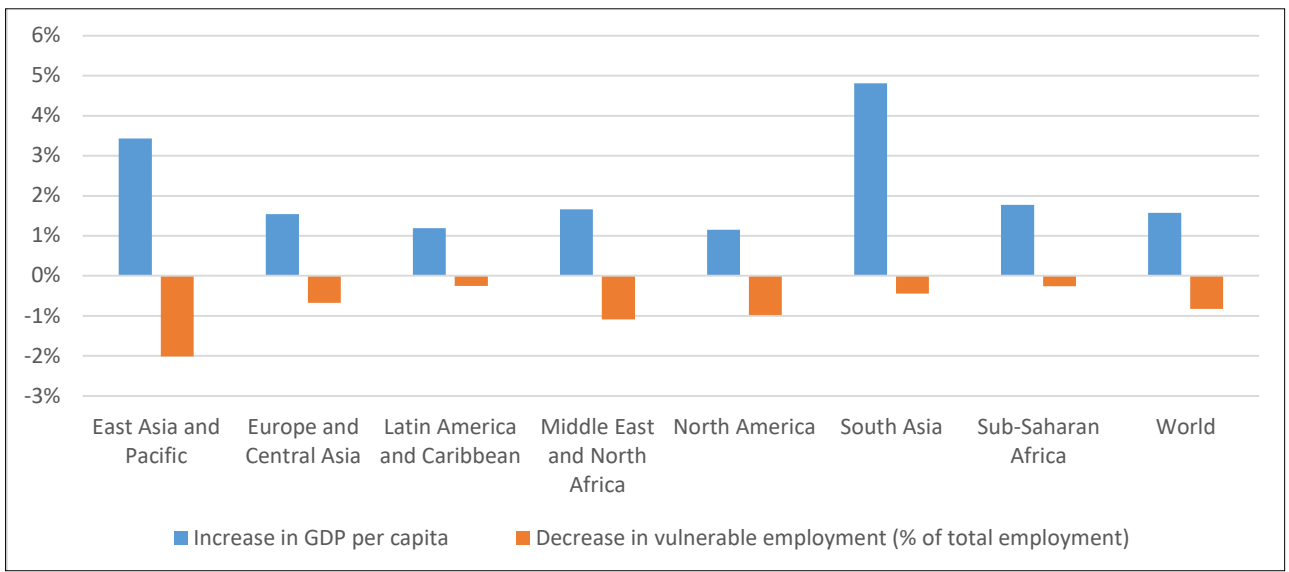

Figure 5.7 Economic growth and the decrease in the share of workers in vulnerable employment over 20 years (1998-2017) (Source: Data taken from development indicators, World Bank, 2019)

Making urbanisation a transformative force for economic development and sustainability requires promoting distributed economies across the continuum of human settlements. Sustainability and technology, if harnessed, can enable African countries to leapfrog. Figure 5.8 shows transformative forces for a new economy. As shown in the diagram, two revolutions can significantly shape economic transformation in the rapidly urbanising Africa, namely the new industrial revolution and the green revolution.

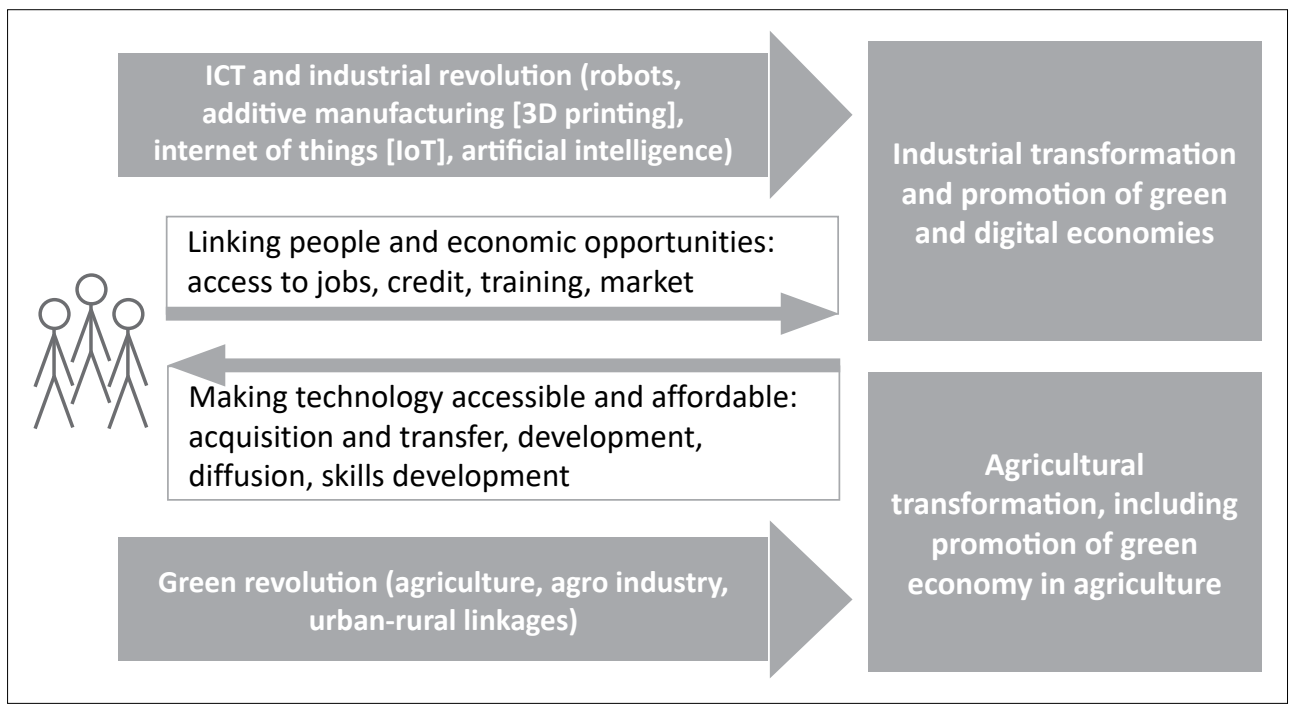

Figure 5.8 Transformative forces for a new economy 
New industrial revolution: Many African countries have embarked on second-generation industrial policies to reset their industrial development. This overlaps with the new industrial revolution, which includes advanced automation (robots), additive manufacturing (3D printing), the internet of things (IoT) and artificial intelligence. Africa may be lacking an industrial base to build on but going by its experience with ICT this should not necessarily exclude it from benefiting from some of the industrial applications of the new technologies. By investing in research and development, ${ }^{14}$ Africa can harness these technologies to catalyse productivity, decentralise and democratise production and innovation in a range of sectors including agriculture, food and construction, as well as tradeable service sectors. The fledgling digital and green economies, both in the rural and urban contexts, can benefit from the new industrial technologies.

Green revolution: Africa is a net food importer and over 80 percent of the population in many low-income countries remains engaged in agriculture. High food prices are suggested by some as the key factor undermining the competitiveness of manufacturing in Africa. Modernising and transforming agriculture, in a policy context favouring small rural and urban producers, offers enormous job and economic opportunities and fosters urban-rural linkages, especially in low-income countries. The new twenty-first-century green revolution, in contrast to the first green revolution of the nineteenth and twentieth centuries, is not only aimed at increasing productivity and income, which remain central to combating poverty and achieving food security in Africa, but it is also aimed at fostering sustainability. It involves the use of ICT tools in a variety of ways, such as market access, weather information, and training and extension services. It also draws on agro-ecological approaches, bio-technologies, and green economy applications ranging from renewable energy to afforestation, water conversation and waste recycling.

Both low- and middle- income countries can benefit from the new industrial and green revolutions. Success hinges on the ability to harness technologies (innovation systems that links research and development, industry and finance) and the capacity to connect people and economic opportunities (access to skills, market, land, finance and infrastructure).

In recent years, the debate around whether industrial development can be a pathway for structural transformation in Africa has been intensified. Manufacturing

14 A 2018 report by UNECA on the performance of SDGs in Africa identified Kenya, Morocco, South Africa and Tunisia, among countries investing a larger share of GDP in science, technology and innovation to tap on technological opportunities (AU, UNECA, AfDB \& UNDP, 2018). 
production has doubled since 2000 and has been growing by 3.5 percent annually in real terms in the last decade. However, the share of manufacturing in GDP has shrunk from 18 percent in 1975 to 11 percent in 2015 and the region remains a peripheral player in global manufacturing export. But experience varies across countries, ranging from those aggressively promoted FDI in food and garment industries through special economic zones (SEZs), ${ }^{15}$ such as found in Ethiopia, to mature economies such as South Africa and Morocco, both of which promoted industrial capabilities in automobile industries. Nigeria and South Africa, followed by Kenya, Democratic Republic of Congo, Côte d'Ivoire, Ethiopia and Tanzania show a relatively strong manufacturing base, while Ethiopia shows strong growth, albeit from a low base. Garment and footwear, agro-processing, horticulture and automobiles are sighted as promising sectors. Overall, the region faces two challenges: First, competition from a new wave of Asian producers like Bangladesh, Cambodia and Viet Nam, which mostly benefit from advantages of lower wages, higher productivity or better infrastructure (Balchin et al., 2016). Second, the potential re-shoring of industry to developed countries that may stand to benefit from the fourth (new) industrial revolution.

Hence, Africa needs to narrow the digitisation gap to achieve the unconditional convergence gains of manufacturing, which will be increasingly robotised. Econometric evidence suggests a slowdown in manufacturing labour productivity in sub-Saharan Africa in 2002-2013 compared to 1991-2002. As the economy becomes more digital, the impact of technological progress on productivity increases, but again this effect is lower in LICs [low-income countries] and SSA [sub-Saharan Africa]; (Banga \& te Velde, 2018:vi). An increasing share of manufacturing in the twenty-first century will increasingly see an increased demand for products associated with higher skills, complexity and technology level.

Africa still has a window of opportunity to exploit its comparative advantages in labour-intensive industries, while speeding up narrowing the digital divide. Kenya shows the way to go. Kenya's often-cited promising development in digitisation is a result of strategic initiatives including the introduction of mobile money (M-Pesa, 2007), the incorporation of ICT as a key pillar in the government's

15 Special economic zones (SEZs) are designated geographical areas set aside for specifically targeted economic activities. These industrial hubs are supported through special incentives and trade laws that differ from the rest of the country. 'They are typically established with the aim of achieving one or more of the following four policy objectives: (i) Attracting foreign direct investment (FDI); (ii) Serving as "pressure valves" to alleviate large-scale unemployment; (iii) Supporting a wider economic reform strategy; and (iv) Acting as experimental laboratories for the application of new policies and approaches' (Farole, 2011:1). Saldanha Bay in the Western Cape and Coega in the Eastern Cape are examples of South African SEZs. 
2030 vision, investment in undersea fibre-optic cables and high-speed internet (2010), and the launch of array of programmes, including the Kenya Open Data Initiative (2011), the National Broadband Strategy (2013), the National CyberSecurity Strategy (2014) and the National ICT Masterplan (2017) (Banga \& te Velde, 2018). The results of these early initiatives are showing, not only in the increased general digital literacy and financial inclusion but also in the new generation of industries and capabilities. Examples include:

Proteq Automation, offering the latest in industrial automation technology and machine manufacturing; Homgenius, developing an automated bricklaying machine that can make more than 2000 interlocking building blocks per day; AB3D, acting as a one-stop-shop for 3D printing in Nairobi and offering low-cost access to 3D printers; and several cloud-based business management start-ups. (Banga \& te Velde 2018:40)

\section{Where to from here?}

In this chapter, drawing on the literature, we have synthesised the growing consensus on urban realities in Africa and raised strategy policy issues for transformative urbanisation. The next sections introduce illustrative tools that can support policy actions. The key messages that came out of the policy discussion underscore that business as usual does not work and pairing urbanisation and technology offer 'leapfrog' opportunities to Africa. But action is needed before the window of opportunities closes. Africa may not have a large stock of capital or assets of old technology to dispose of or retrofit and thus may not have to deal with a big risk of 'stranded assets' or lock-in effects. However, structural factors, such as poverty, human, financial and institutional barriers and technological gaps, remain formidable challenges. This chapter does not offer a new template for urban development but highlights the broad sets of principles and levers of change.

Through the lens of these principles, African countries should assess current urban practices, programmes and initiatives at both national and subnational levels. The array of initiatives, including smart cities, tech cities and new cities offer a glimpse of the future but are neither inclusive nor scalable. Africa needs a new urban model that is inclusive and sustainable. Financial considerations may make private sectorled urban development attractive, but it is questionable whether achieving just and sustainable cities without a shared vision and rules of the game and coordination across sectors and levels of government is in the interest of the public good. Transformative urbanisation should be a priority and should be mainstreamed in the policy, investment planning and budgeting cycle. 
Supporting tools for strategic decision-making and planning

As a cross-cutting phenomenon intersecting different themes, there are plenty of relevant tools supportive of sustainable urbanisation. But here we focus on illustrative and strategic tools, representing national, city and local levels or scales. These are related to national development planning, urban planning and local economic development. Figure 5.9 shows these tools at different scales.

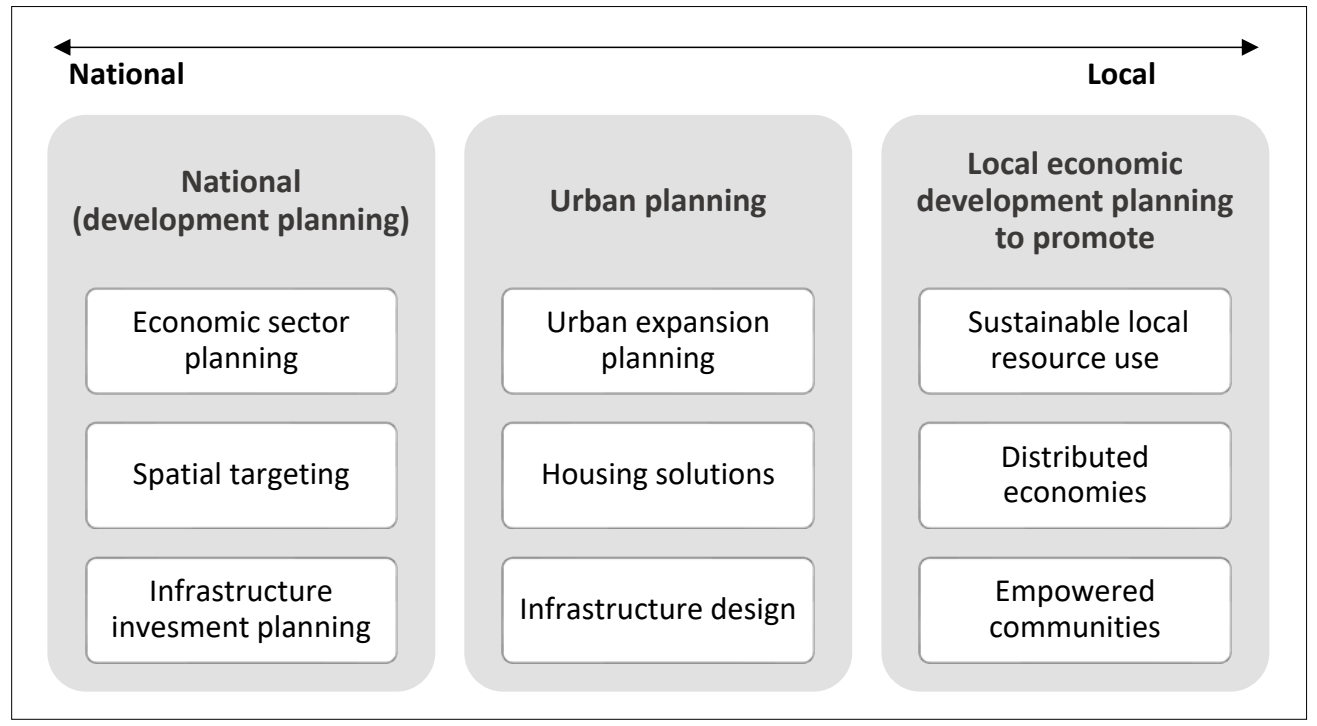

Figure 5.9 Tools at multiple scales

\section{Integrating urbanisation into national development planning}

Africa is undergoing urban, economic and demographic changes. All three are major forces impacting the nature, pace and scale of its transition to sustainability and require a concerted policy action at the national scale. National development planning provides a strategic platform to do this. Economic sector and infrastructure planning should have a spatial lens, and spatial targeting of investments should be based on economic and sustainability considerations. ${ }^{16}$ The paragraphs that follow consider some of the many reasons for the need to integrate urbanisation into national development planning.

\section{Macro-economic and sector priorities}

Macro-economic and sector priorities as defined in national development plans have strong spatial and urban implications. Sector priorities determine whether

16 Related economic, investment and spatial tools are key to planning and implementing a sustainable urban system. 
growth is job-rich or job-poor and whether there is a potential shift in economic geography and economic prospects of different regions. Implicitly or explicitly, development plans influence trends in urbanisation and urban structure.

\section{Urbanisation}

Urbanisation levers growth and transformation but comes at a cost. The present and future cost of building new cities and improving existing cities and settlements should be factored into investment planning and project programming. Longterm environmental considerations and growth trajectories determine the nature and level of investment, making the cost of urbanisation vary with context and development scenarios. According to Harry Richardson, the cost of urbanisation includes:

direct investment costs (i.e., the costs of creating jobs), housing and intraurban infrastructure costs (primarily the capital costs of urban services such as shelter, water, sanitation, electricity, social services, etc.), inter-urban (or interregional) infrastructure costs, and growth-management costs. (Richardson, 1987:564)

\section{Urban investment}

Urban investment is the total of public, private and household investment. Coordinating investment across these three sources is an essential condition for building sustainable cities. Failure to coordinate investment by the different actors leads to settlements without infrastructure or jobs, or infrastructure without firms, or vice versa. This results in dysfunctional cities, a waste of resources and the loss of positive externalities.

\section{Public investment}

Public investment is heavily directed to infrastructure. The way infrastructure is designed determines urban efficiency and sustainability. Therefore, with the huge amount of investment going to urban infrastructure in the coming years and decades, government becomes a critical lever in influencing Africa's transition to sustainability. With the right policies, technology and institutions, future cities can become productive, and at the same time resource efficient.

\section{A multi-level governance context}

In a multi-level governance context, coordination across levels of government is also extremely important in achieving sustainable urbanisation. Aligning sector and territorial priorities and linking planning and implementation capacities of different levels of government is necessary to marshal resources and action for sustainable development. 


\section{Box 5.1: Decision-making tools useful in infrastructure investment planning and prioritisation $^{17}$}

Alignment and prioritisation of investment is a complex process with far-reaching and long-lasting impacts. The National Research Council (2014) of the US has suggested several decision-making tools that may be useful in this process.

\section{Benefit-costs analysis}

Benefit-costs analysis (BCA) is embedded in traditional economic analysis. It is now being used more and more to analyse the social and environmental impact of decisions. Fundamentally, BCA provides a process and way to compare alternatives, and more clearly understand trade-offs. It is also important to assess the distribution of benefits and costs across different social groups arising from a decision. There may be winners and losers in the process. For example, a city may grapple with investing in poor urban areas to reduce urban poverty and social disparities or investing in a richer part of the city and achieve higher financial return or growth. Most decisions have direct and indirect effects that need to be anticipated during the planning and decision phase. Some of these effects are short term and others long term. Short-term benefits may be offset by more weighty long-term costs, which in some cases, could be irreversible and more damaging to sustainability. There also may be unintended consequences that need to be understood as actions are implemented and the cascading effects materialise. For example, the decision to invest in housing projects on the urban periphery may benefit in the short term from cheaper land costs, but over time the development contributes to sprawl, energy and transport costs.

In the context of urban development, benefits could involve multiple criteria or metrics, and therefore analysis may involve looking at the multiple impacts of each decision option. There are many critiques of BCA, especially in the context of sustainability. A common outcome of BCA analysis is an attempt to monetise as many of the benefits or costs as possible of each alternative under consideration and present the results as a single monetised result. Costs or benefits that are more difficult to monetise are either ignored, relegated to a description that is not given the same weight as the more easily measured and monetised effects or they are subject to other controversial economic techniques that attempt to 'price the priceless' (e.g., contingent valuation). Another challenge of BCA in the context of urban sustainability is related to intra- and inter-generational distributional aspects. Benefits accruing to different social groups or future generations may require assigning different weights and discount rates, respectively, and these can be controversial.

\section{Cost-effective analysis}

A related tool to $\mathrm{BCA}$, cost-effective analysis (CEA) is aimed at selecting the least cost option among equally effective decision options. In the resource-scarce or deficient context of Africa, identifying the option that provides the maximum benefits with the least cost is an overriding objective in decision making. Sometimes the initial cost of intervention could appear cheaper or less, but may involve much higher long-term costs and therefore, accounting for all future costs in the decision making is critical. Some infrastructure investments may look cheap on the face of the initial cost but may end up to be much more costly when long-term social and environmental costs or operational costs are considered.

17 The tools described are adapted from the National Research Council (2014) of the US. 


\section{Life-cycle assessment}

Life-cycle assessment (LCA) approaches to decision making involve considering all relevant aspects of a product or system along the different stages or phases of the life cycle. LCA helps in that the implications of decisions and their consequences are fully considered as part of a larger system, and not as isolated parts.

\section{Risk analysis}

A risk analysis (RA) is done to evaluate the relative merits of options in terms of risk management by making more explicit the likelihood and magnitude of consequences. It is particularly important in long-term decisions and uncertainties. It involves three questions: What can go wrong? What are the chances that something with serious consequences will go wrong? What are the consequences if something does go wrong? (Kaplan \& Garrick, 1981). Part of the reason for involving local officials and communities in urban development and planning is to address concerns and risks stakeholders may have and to build trust and confidence.

\section{Urban planning}

Resource efficiency and urban productivity hinges on urban form, which is shaped by urban layout, density and connectivity, and infrastructure design. Urban planning is a key tool for achieving that.

Many African cities had master plans, but for the most part, the grand ideas and visions of those plans did not materialise. By the time the plans were completed, the realities on the ground had been utterly changed by the rapid forces of urbanisation. The cities are poor financially and have a weak capacity to implement, adjust, or respond. The plans remain static and rigid, while the realities constantly evolve. Big projects involving big players and resources strain local capacity, and in the meanwhile the issues and problems the cities face grow in scale and complexity, prompting a plethora of projects and bottom-up initiatives. The dynamism and ingenuity generated in bottom-up approaches, and the static and rigid planning and control interventions struggling to cope with old and new challenges, co-exist with limited interaction on the margin, resulting in chaotic urban development.

The failure of large-scale planning in African cities is manifested in the continuing growth of slums. The big developers target the rich and the upper-middle class, while the majority turn to building shacks. Under the pressure of the market forces and land encroachment by the disfranchised urban poor, the dream plans remain unfulfilled, and everyone loses. Studies from Latin America indicate that retrofit solutions or upgrading of slums are up to 12 times more costly. When land is laid out efficiently, the provision of services and incremental housing should offer a much cheaper option. 


\section{Box 5.2: When bottom-up meets top-down: Turning planning on its head}

Building sustainable communities and cities demand turning the command and control top-down planning process from one of static and deterministic to enabling and generative, responsive and facilitative. The top-down planning approach that is fixated on endstates has relied on complex policies and development control tools. On the other hand, bottom-up approaches are guided by simple rules that are informed by practice, norms and traditions, but decidedly determined the urban form and development. Unlike top-down rigidity, bottom-up approaches are aligned to emergent or adaptive solutions and driven by collaborative and self-organised collective actions.

As highlighted in Figure 5.10, The key remedy to the deficiency of top-down planning lies in changing planning from place-making to condition-making. In the new approach, cities will be viewed as complex adaptive systems that evolve as living organisms and incrementally change through multiple actions of small actors. Thus urbanism is seen not as a closed set of rules, but as an open system that continuously interacts and evolves with its environment. Planning by government and the 'emergent vernacular' of the people overlap and interact. Planning in this context provides the essential conditions that set the boundaries and constraints within which creativity and innovation flourish to build sustainable communities. Simple and tested rules on street and blocks set the essential urban order and starter conditions. Platforms, including scalable strategies, codes, standards and regulations, provide the foundation and necessary support to accelerate change and growth. Defaults provide a typology of solutions at different scales to influence positive choices. Finally, activators focus on enabling mechanisms to build social capital in a variety of scales, catalysing collective action for change.

The range of tools for each of these planning components include an urban expansion plan, which is an incremental approach where the initial effort is focused on land acquisition and protection of the right of way, followed by multi-year phased investment; ${ }^{18}$ grid-based simulation for facilitating layouts and testing the metrics for a full range of development scenarios; dweller adaptive building systems, which segment actions during development and dwelling to allow fit-for-purpose uses and future changes of housing and commercial buildings, promote innovation, and balance between distinctiveness and affordability; a parameter-based building typologies facilitating meeting a spectrum of needs; and citizen engagement tools ranging from neighbourhood gaming technique to participatory budgeting geared to fostering collective actions (Campbell, 2018).

18 The New York University Stern Urbanisation Project promotes a simple four-step municipal action programme that focuses on preventing the occupation of the urban fringe by formal and informal construction, prior to the necessary preparations. These preparations include (a) projecting population and urban area per capita growth 25 years out and developing maps; (b) creating a single municipal jurisdiction that can execute plans in the entire area for expansion; (c) locating an arterial road grid with a 1-kilometer spacing throughout the expansion area and transferring the rights-of-way for all roads to the municipality to prevent incursion by formal and informal developers (Lamson-Hall et al., 2015). UN-Habitat promotes similar approach, coupled with a financing plan and a supportive package of urban regulations. 


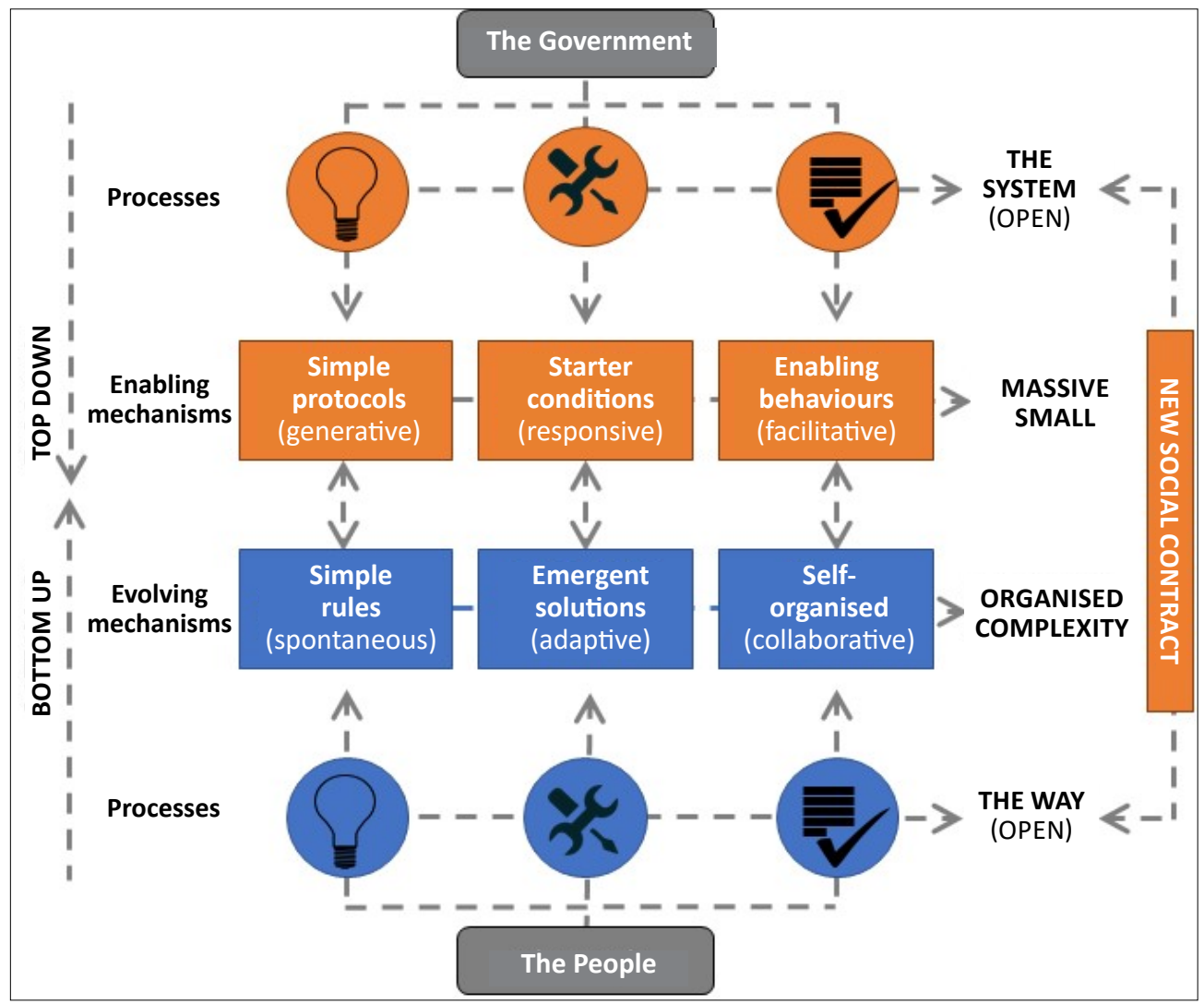

Figure 5.10 A new framework for top-down plus bottom-up planning (Source: Adapted from Campbell, 2018:82)

The solution lies neither in the top-down command and control system nor in the bottom-up self-development. What is needed is light-touch top-down planning to provide guidance and structure while allowing adaptation and innovation to suit diverse needs, and bottom-up initiatives that are spontaneous, adaptive and collaborative. The key is transforming the top-down planning from a system that constrains to a system that enables by moving from complex policies aimed at fixed end states to policies that provide simple and generative protocols geared to facilitating massive small changes that are adaptive, responsive and creative. The idea is making planning dynamic and accommodative by focusing on starter conditions and enabling behaviours and liberating the forces of creativity and collective actions residing in bottom-up approaches (Campbell, 2018). 


\section{Box 5.3: Financing tools}

One of the central challenges African cities face is financing. Local authorities should be empowered to raise revenues and access external sources to implement urban plans. There are a host of under-utilised local revenue sources and emerging innovative financing vehicles. Two such tools are highlighted below:

\section{Urban land value capture}

Public investment in infrastructure increases land value, and in many countries, this has been an important source of local revenues for investment. By capturing part of the increased wealth and value appreciation generated through public investment, cities can expand their investment pool and sustain a virtuous link between public investment, growth and taxes. Land and property taxes, capital gain taxes, betterment fees and infrastructure exaction are some of the instruments available to capture increased land value. Due to political and administrative and technical capacity constraints, African cities fail to sufficiently exploit this important revenue source, however, there is a potential to change this. ${ }^{19}$

\section{Green bonds}

Green bonds are generally used to finance green infrastructure projects. In comparison to conventional bonds, the volume of green bonds is relatively small but growing. Out of a total of $\$ 131$ billion estimated to have been raised in 2016 , only $\$ 2.3$ billion was invested in cities in developing countries (Oliver, 2016). In 2013, AfDB issued a $\$ 500$ million green bond, and over the last five years, two South African metropolitan governments, Cape Town and Johannesburg, have issued green bonds. Beyond the additional money generated for infrastructure development, green bonds provide an environmental credential that can be attractive to a new pool of investors (Duru \& Nyong, 2016) and thus should be a financing instrument worth pursuing within the context of sustainable development.

\section{Local economic development planning}

Distributed economies, a critical component of sustainability in Africa, demand harnessing local capacities, resources and skills. Local economic development (LED) represents a suite of tools available for harnessing local potentialities. Local economic development is essentially inclusive because it is participatory and broadbased; it is sustainable because it balances social, economic and environmental goals; it is strategic because it forces communities to make hard choices that matter most to their long-term prosperity and sustainability. Most common local solutions, from waste recycling and home-based enterprising to time banking, resonate with the tenets of sustainability and distributed economy.

Local economic development is used by both economically vibrant and economically distressed cities, urban areas and communities. Cities with agglomeration economies use LED to leverage their spatial and natural advantages and stay economically

19 Land and property tax in Africa is estimated at 0.5 percent of GDP compared to 2 percent in developed economies (UNECA, 2019, forthcoming). 
competitive, while communities in economically less productive areas use LED to improve their economic prospect by reimagining and creating new opportunities and exploiting their hitherto underutilised resources. Even in developed economies, including the US, governments target poor cities, through tax breaks and other incentives, to help them lure investment, or create and retain jobs. ${ }^{20}$

Local economic development planning is a cross-cutting tool used to mobilise communities, create a shared vision and mobilise resources to achieve specific goals and objectives, such as job creation and local sustainability. The following paragraphs discuss some of the variety of tools that can be used in LED planning.

\section{Local economic profiling}

Local economy profiling applies different tools to identify and assess the economic base and drivers, as well as challenges and threats. It traces underlying changes and shifts within and between growing, declining and emerging sectors. It also assesses local resources and capacity (human, natural and physical, financial and cultural) and their sustainability.

\section{Asset-based community development}

Asset-based community development is a local sustainable development approach which draws on strength and potentials possessed by host communities. Strength could be both tangibles like location, water and land resources, or intangibles such as social capital, cultural assets, networking and leadership. Community asset mapping is used to take stock of individual assets (talents and skills), associations (cultural bodies, interest groups and religious organisations) and local institutions (business, industry, education), and other resources that can be deployed to promote economic growth and sustainability.

\section{Capacity inventory}

As a variant of asset-based community development, this tool identifies and takes stock of a range of skills (individual, community and enterprise) and also personal interests. The information helps to mobilise and exploit human capacity existing in the community for sustainable development.

\section{Urban development LED strategy tools}

Urban development LED strategy tools include a host of technical, spatial and regulatory instruments used to promote urban sustainability as a lever for economic development. Examples include pedestrian and cycling master plans with design

20 The Opportunity Zone Scheme of the US which was introduced in 2017 is one such example and targets distressed communities for preferential tax treatment. 
guidelines, green development guides, urban forests, climate adaptation guides, energy planning, transportation plans, urban containment boundaries, sustainability checklists, zoning bylaws; and smart neighbourhoods.

\section{Sector-specific LED strategy tools}

Sector-specific LED strategy tools include sector-specific tools deployed to leverage sustainable economic development, for example, tourism planning, agro-industrial development plans, and ICT development.

\section{Social enterprising}

Social enterprising involves processes aimed at establishing the third sector (neither public nor private) to generate solutions in areas where both the public and private actors failed or to promote a social economy as the basis for a sustainable, prosperous and inclusive society. In a digital economy, social economies can foster the power of the web and the community to create a vibrant economy that is inclusive and sustainable.

\section{Time banking}

Time banking is a mechanism connecting individual assets to foster collective action or to facilitate transaction towards meeting individual and social needs of sustainable communities. By using time as currency, people can turn their assets into economic and social goods. Sweat capital of slum dwellers in slum improvement projects or volunteers participating in green projects could also be viewed in a similar light.

\section{Crowdsourcing}

Crowdsourcing is an open system used to generate ideas and solutions or to mobilise capital and thus support building collective intelligence or unlocking financing capacity residing in the local community or beyond.

\section{Participatory processes}

Local economic development is essentially a participatory process built around shared aspirations, will and collective actions. Local leadership and demand-driven technical support are critical ingredients for success. When linked with resource allocation, the participatory process becomes a powerful tool of decision making with real consequences. Participatory budgeting which started in Port Alegre (Brazil) and adapted in many cities of both developed and developing countries is one such tool used to allocate public resources based on priorities set by communities. 


\section{Conclusion}

Africa is urbanising rapidly in the context of weak industrial development and without a green revolution. A comparison with East Asia brings the point home. Africa is 40 percent urbanised with an annual per capita income of about $\$ 1000$. The respective figures for East Asia and Latin America were \$3 617 and \$1 860 when they reached the same level of urbanisation in 1994 and 1950 respectively, reflecting the relatively weak link between urbanisation and economic growth in Africa (Henderson \& Kritikos, 2017).

As a result, African cities face multiple challenges including housing and infrastructure deficits, chronic unemployment, growing informality and premature diseconomies manifested in urban sprawl, congestion and an increasing cost of living and business.

But urbanisation is inherently good for development, if well managed. Two-thirds of investment in African urban infrastructure needed by 2050 is yet to be made (Muggah \& Hill, 2018), and this has huge implications for investment and job creation, and also for charting a non-conventional development path that is lowcarbon, inclusive and sustainable. Considering its speed and scale, urbanisation in Africa is disruptive and traumatic, but it is also a force to be reckoned and leveraged for sustainable development. Africa does not have much time left to consummate its urban transition; an opportunity that should not be missed. The opportunities far outweigh the challenges.

The overarching policy question, therefore, is how to seize these opportunities and turn them into development conditions favourable to low-carbon, inclusive and sustainable development. The urban policy and strategy issues critical to sustainability in Africa are centred on four themes: the system of cities, housing, infrastructure and productive urban or local economies.

Africa is a huge continent and countries are diverse in their context. It is thus impossible to spell out the policy agenda suited or relevant to every case. Therefore, the policy issues discussed in the chapter are generic, though contextual specificities, such as level of income and urbanisation, are considered where appropriate. Some of the policy interventions, such as planning urban expansion, are beneficial to all countries, albeit with varying degrees of urgency. In many cases, urban policy issues cross-cut sectors, geographic scales and governance levels. Accordingly, the set of tools presented in this chapter to address the policy issues illustrate national, city and local level interventions. 
Technology in renewable energy, mobility, and information and communications offer new opportunities for Africa to leapfrog. The emerging technology for minigrid and decentralised energy systems is particularly important in the context of dispersing urban functions and promoting distributed economies. In the African context, technological and infrastructure transitions need to take into consideration the co-existence of alternative solutions and heterogeneous sociotechnical systems. 


\section{References}

African Development Bank. (2018). African economic outlook 2018. Abidjan: AfDB.

African Development Bank, Organization for Economic Co-operation and Development \& United Nations Development Programme. (2016). African economic outlook 2016: Sustainable cities and structural transformation. Paris: OECD Publishing. https://doi.org/10.1787/aeo2016-en

African Union, Economic Commission for Africa, African Development Bank \& United Nations Development Programme. (2018). 2018 Africa sustainable development report: Towards a transformed and resilient continent. Addis Ababa: UNECA.

Angel, S., Lamson-Hall P., Madrid, M., Blei, A.M. \& Parent, J. (2016). Atlas of urban expansion (Vol. 1). NYU, UNHabitat \& Lincoln Institute of Land Policy.

Avila, N., Carvallo, J.P., Shaw, B. \& Kammen, D.M. (2017). The energy challenge in sub-Saharan Africa: A guide for advocates and policy makers: Part 1: Generating energy for sustainable and equitable development. Oxfam Research Backgrounder series. https://bit.ly/2kGdbd2 [Accessed 25 September 2019].

Balchin, N., Gelb, S., Kennan, J., Martin, H., te Velde, D.W. et al. (2016). Developing export-based manufacturing in sub Saharan Africa. London: ODI, SET Programmes.

Banga, K. \& te Velde, D.W. (2018). Digitalisation and the future of manufacturing in Africa. London: ODI, SET Programmes.

Barhoumi, K., Vu, H., Towfighian, S.N. \& Maino, R. (2018). Public investment efficiency in sub-Saharan African countries: What lies abead? Washington, DC: IMF. https://doi. org/10.5089/9781484360019.087
Barofsky, S.A. (2016). Can rapid urbanisation in Africa reduce poverty? Causes, opportunities and policy recommendations. Washington, DC: Brookings Institute.

Bloch, R., Makarem, N., Yunusa, M., Papachristodoulou, N. \& Crighton, M. (2015). Economic development in urban Nigeria. Urbanisation research Nigeria (URN) Research Report. London: ICF International.

Brahmbhatt, M.B. (2016). Africa's new climate economy: Economic transformation and social and environmental change. Washington, DC: New Climate Economy and ODI.

Calderón, C. (2009). Infrastructure and growth in Africa. Washington, DC: World Bank. https://doi.org/10.1596/1813-9450-4914

Campbell, K. (2018). Making massive small changes. London: Chelsea Green Publishing.

Christiaensen, L. \& Todo, Y. (2013). Poverty reduction during the rural-urban transformation: The role of the missing middle. Washington, DC: World Bank. https://doi.org/10.1596/1813-9450-6445

Collier, P. (2016). African urbanisation: An analytic policy guide. London: The International Growth Centre.

Collier, P. \& Venables, J.A. (2012). Greening Africa? Technologies, endowments and the latecomer effect. Energy Economics 34(20): 575-584. https://doi.org/10.1016/j. eneco.2012.08.035

Collier, P. \& Venables, J.A. (2014). Housing and urbanisation in Africa: Unleashing a formal market process. Washington DC: World Bank Group. https://doi. org/10.1596/1813-9450-6871

Commission on Growth and Development. (2008). The growth report: Strategies for sustained growth and inclusive development. Washington, DC: World Bank.

Coulibaly, B.S. (Ed.). (2019). Foresight Africa: Top priorities for the continent in 2019. Washington, DC: Brookings Institute. 
Currie, P. (2015). A resource flow typology of African cities. Master's thesis, Stellenbosch University, South Africa.

Currie, P., Lay-Sleeper, E., Fernandez, J.E., Kim, J. \& Musango, J.K. (2015). Towards urban resource flow estimates in data scarce environments: The case of African cities. Journal of Environmental Protection 6(9): 1066-1083. https://doi.org/10.4236/ jep.2015.69094

Currie, P. \& Musango, J.K. (2017). African urbanisation: Assimilating urban metabolism into sustainability discourse and practice. Journal of Industrial Ecology 21(5): 1262-1276. https://doi. org/10.1111/jiec.12517

Dorosh, P. \& Thurlow, J. (2014). Can cities or towns drive African development? Economywide analysis for Ethiopia and Uganda. World Development 63: 113-123. https://doi.org/10.1016/j. worlddev.2013.10.014

Duru, U. \& Nyong, A. (2016). Why Africa needs green bonds. Africa Economic Brief $7(2): 1-8$.

Eberhard, A., Rosnes, O., Shkaratan, M. \& Vennemo, H. (2011). Africa's power infrastructure investment, integration, efficiency. Washington, DC: World Bank. https://doi.org/10.1596/978-0-8213-8455-8

Farole, T. (2011). Special economic zones: What have we learned? Economic Premise 64: 1-5. https://doi. org/10.1596/9780821386385_Over

Foster, V. \& Briceño-Garmendia, C. (2010). Africa's Infrastructure: A time for transformation. Washington, DC: World Bank. https://doi.org/10.1596/978-08213-8041-3

Fox, L., Thomas, A. \& Haines, C. (2017). Structural transformation in employment and productivity: What can Africa hope for? Washington, DC: IMF.

Friedman, J. (1996). Modular cities: Beyond the rural-urban divide. Environment and Urbanization 8(1): 129-131. https://doi. org/10.1177/095624789600800107
Godfrey, N. \& Zhao, X. (2015). The contribution of African cities to the economy and climate: Population, economic growth and carbon emission dynamics. Technical note. London: The New Climate Economy.

Hamer, A.M. \& Linn, J.F. (1987). Urbanisation in the developing world: Patterns, issues and policies. Handbook of Regional and Urban Economics 2: 1255-1284. https:// doi.org/10.1016/S1574-0080(87)80018-4

Harris, R. \& Arku, G. (2006). Housing and economic development: The evolution of an idea since 1945. Habitat International 30(4): 1007-1017. https://doi. org/10.1016/j.habitatint.2005.10.003

Henderson, J.V. (2010). Cities and development. Journal of Regional Science 50 (1): 515-540. https://doi.org/10.1111/ j.1467-9787.2009.00636.x

Henderson, J.V. \& Kritikos, S. (2017). The development of the African system of cities. London: London School of Economics.

Honeywell \& Ernst and Young. (2015). Smart buildings make smart cities. https://bit.ly/2OYe8Lm [Accessed 18 September 2019].

Jedwab, R., Christiaensen, L. \& Gindelsky, M. (2014). Rural push, urban pull and... urban push? New historical evidence from developing countries. Washington, DC: George Washington University.

Kaplan, S. \& Garrick, B.J. (1981). On the quantitative analysis of risk. Risk Analysis 1(1): 11-27.

Lamson-Hall, P., Degroot, D., Martin, R., Tafesse, T. \& Angel, S. (2015). A new plan for African cities: The Ethiopia urban expansion initiative. https://bit.ly/31 uwwxQ [Accessed 15 September 2019].

Modisaatsone, N. (2014, 11 April). A different kind of smart city. [Web log post]. https://bit.ly/2Br8gCc [Accessed 20 September 2019]. 
Muggah, R. \& Hill, K. (2018, 27 June). African cities will double in population by 2050 . Here are 4 ways to make sure they thrive. [Web log post]. https://bit.ly/2KcyCPb [Accessed 20 September 2019].

National Research Council. (2014). Sustainability concepts in decisionmaking: Tools and approaches for the US Environmental Protection Agency (2014). Washington, DC: The National Academies of Sciences, Engineering, and Medicine.

Newfarmer, R., Page, J. \& Tarp, F. (Eds). (2018). Industries without smokestacks: Industrialization in Africa reconsidered. WIDER Studies in Development Economics. Oxford: Oxford University Press. https://doi.org/10.1093/ oso/9780198821885.001.0001

Oliver, P. (2016). Green bonds for cities: A strategic guide for city-level policymakers in developing countries. https://bit.ly/2MtE2F6 [Accessed 15 September 2019].

Oxford Economics. (2017). Global infrastructure outlook. Oxford: Oxford Economics.

Potts, D. (2009). The slowing of sub Saharan Africa's urbanization: Evidence and implications for urban livelihoods. Environment and Urbanization 21(1): 253-259. https://doi. org/10.1177/0956247809103026

Richardson, H.W. (1987). The costs of urbanisation: A four-country comparison. Economic Development and Cultural Change 35(3): 561-580. https://doi. org/10.1086/451604

Rogers, M. \& Pedros, X. (2017). Taxing mobile connectivity in sub-Saharan Africa: A review of mobile sector taxation and its impact on digital inclusion. London: GSMA.

Silver, J. \& Marvin, S. (2017). Powering sub-Saharan Africa's urban revolution: An energy transitions approach. Urban Studies 54(4): 847-861. https://doi. org/10.1177/0042098016668105
South Africa Cities Network. (2013). Spatial transformation of cities: Conference report. Braamfontein. https://bit.ly/2BqY4tG [Accessed 15 September 2019].

Stefanski, R. (2010). On the mechanics of the 'Green Solow Model'. OxCarre Working Papers No. 47, Oxford Centre for the Analysis of Resource Rich Economies, University of Oxford.

Sy, A. (2015). African countries rebasing GDP in 2014: Finding evidence of structural transformation? Washington, DC: Brookings Institute.

United Nations Department of Economic and Social Affairs. (2018). World urbanisation prospects 2018. Washington, DC: UN DESA. https://doi. org/10.18356/02486bd4-en

United Nations Economic Commission for Africa. (2016). Economic report on Africa 2016: Greening Africa's industrialization. Addis Ababa: UNECA.

United Nations Economic Commission for Africa. (2017a). Economic report on Africa 2017: Urbanisation and industrialization for Africa's structural transformation. Addis Ababa: UNECA.

United Nations Economic Commission for Africa. (2017b). Urbanisation and national development planning in Africa. Addis Ababa: UNECA.

United Nations Economic Commission for Africa. (2019 forthcoming). The state of urbanisation. Financing development in Africa: The role of cities in domestic resource mobilization. Addis Ababa: UNECA.

World Bank. (2013). Global monitoring report 2013: Rural-urban dynamics and the millennium development goals. Washington, DC: World Bank.

World Bank. (2015). Stocktaking of the housing sector in sub-Saharan Africa: Challenges and opportunities. Washington, DC: World Bank.

World Bank. (2019). World development indicators. https://bit.ly/2G6NXPo [Accessed September 2019]. 